ES/ER/TM-113

\title{
Environmental Restoration \\ Information Resource Management \\ Program Plan
}

Environmental Restoration Program

P.O. Box 2003

Oak Ridge, Tennessee 37831-7298

Date Issued-_September 1994

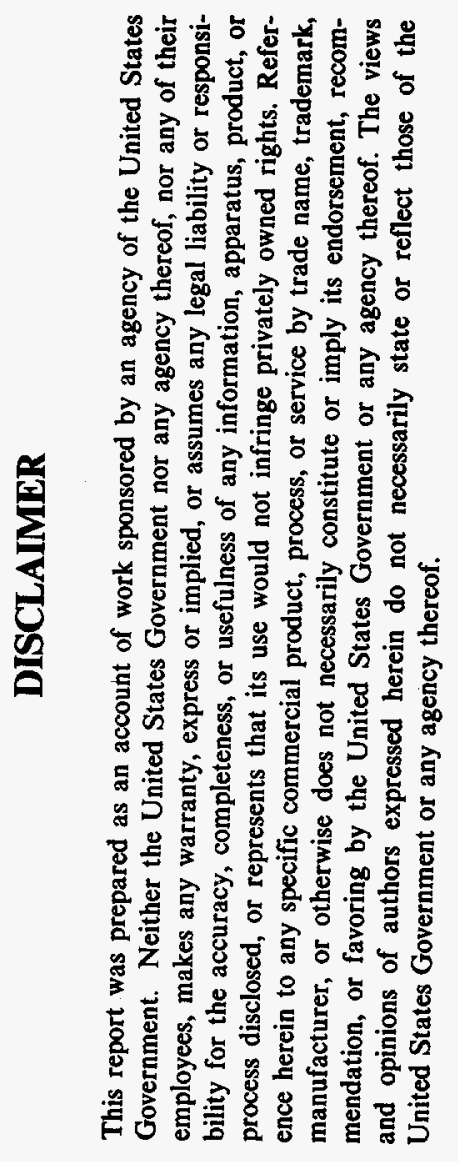

Prepared for

U.S. Department of Energy

Office of Environmental Restoration and Waste Management

under budget and reporting code EW 20

\section{MARTIN MARIETTA ENERGY SYSTEMS, INC. \\ managing the}

Environmental Restoration and Waste Management Programs at

Oak Ridge K-25 Site

Oak Ridge Y-12 Plant

Oak Ridge National Laboratory under contract DE-AC05-84OR21400
Paducah Gaseous Diffusion Plant

Portsmouth Gaseous Diffusion Plant under contract DE-AC05-76OR00001

\section{for the
U.S. DEPARTMENT OF ENERGY WATER}

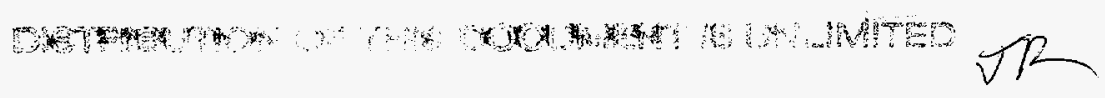





\section{DISCLAIMER}

Portions of this document may be illegible in electronic image products. Images are produced from the best available original document. 


\section{CONTENTS}

TABLES $\ldots \ldots \ldots \ldots \ldots \ldots \ldots \ldots \ldots \ldots \ldots \ldots \ldots \ldots \ldots \ldots \ldots$

FIGURES $\ldots \ldots \ldots \ldots \ldots \ldots \ldots \ldots \ldots \ldots \ldots \ldots \ldots \ldots \ldots \ldots \ldots$

ACRONYMS $\ldots \ldots \ldots \ldots \ldots \ldots \ldots \ldots \ldots \ldots \ldots \ldots \ldots \ldots \ldots \ldots \ldots \ldots$

1. INFORMATION RESOURCE MANAGEMENT

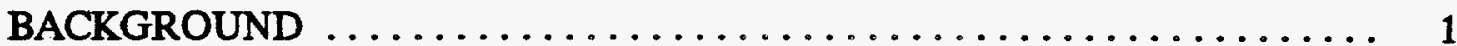

1.1 DOCUMENT PURPOSE $\ldots \ldots \ldots \ldots \ldots \ldots \ldots \ldots \ldots \ldots \ldots \ldots \ldots \ldots$

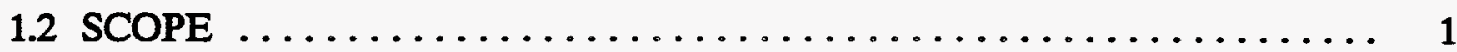

1.3 MISSION STATEMENT $\ldots \ldots \ldots \ldots \ldots \ldots \ldots \ldots \ldots \ldots \ldots \ldots$

2. INFORMATION RESOURCE MANAGEMENT DESCRIPTION . . . . . . 3

2.1 RECORDS MANAGEMENT PROGRAM RISK ASSESSMENT $\ldots \ldots \ldots .3$

2.2 ORGANIZATION, ROLES, AND RESPONSIBILITIES $\ldots \ldots \ldots \ldots \ldots \ldots$

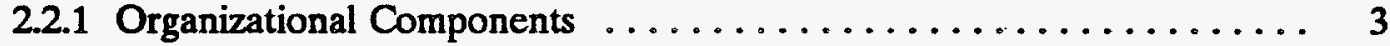

2.2 .2 Roles and Responsibilities .................... 3

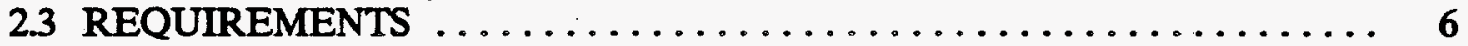

2.3.1 CERCLA AR Requirements ................... 6

2.3.2 DOE/Energy Systems Records Management and Document Control Requirements ............... 7

2.3.3 ER Program/Site Specific Requirements ................. 10

3. INFORMATION RESOURCE MANAGEMENT

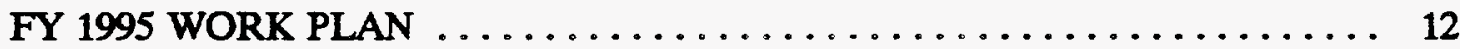

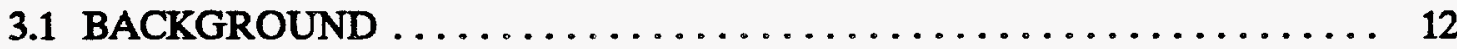

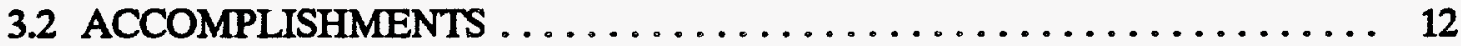

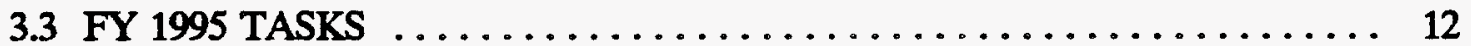

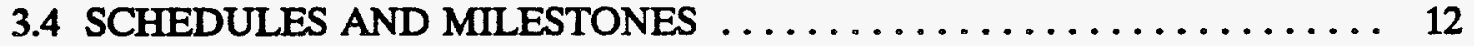

3.5 TECHNICAL PERFORMANCE CRITERIA $\ldots \ldots \ldots \ldots \ldots \ldots \ldots \ldots \ldots$

3.6 INFORMATION AND REPORTING $\ldots \ldots \ldots \ldots \ldots \ldots \ldots \ldots \ldots \ldots$

4. WORK BREAKDOWN STRUCTURE . . . . . . . . . . . . . . . . 14

4.1 ADMINISTRATIVE RECORD-1.4.12.3.04.14.01 $\ldots \ldots \ldots \ldots \ldots \ldots \ldots$.

4.2 PROGRAM ADMINISTRATION-1.4.12.2.3.04.14.02 $\ldots \ldots \ldots \ldots \ldots \ldots \ldots .14$

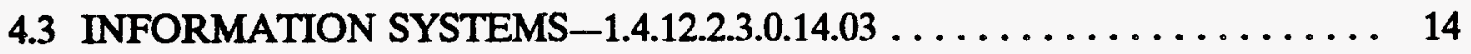

4.4 RECORDS MANAGEMENT AND DOCUMENT

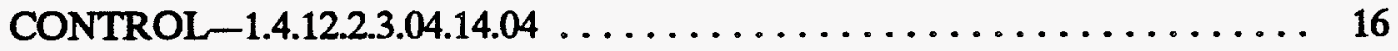

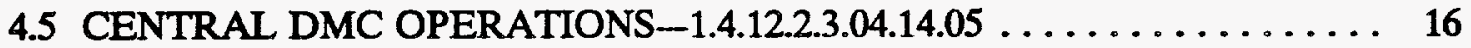

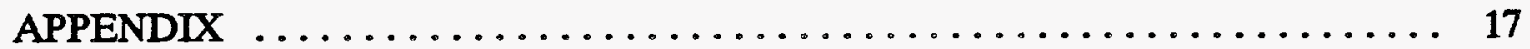




\section{FIGURES}

1. Environmental Restoration Information Resource Management Program

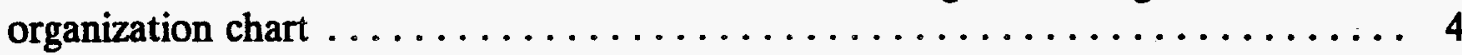

2. Environmental Restoration Program organization chart $\ldots \ldots \ldots \ldots \ldots \ldots \ldots$

3. Work flow process for records in Environmental Restoration $\ldots \ldots \ldots \ldots \ldots$. 8

4. Work flow process for records originated outside Energy Systems $\ldots \ldots \ldots \ldots .9$

5. Work breakdown structure for the Environmental Restoration Information Resource Management Program $\ldots \ldots \ldots \ldots \ldots \ldots \ldots \ldots$. 15

\section{TABLES}

1. CERCLA Administrative Record requirements ................. 19

2. DOE-ORO ER Program and Energy Systems records management and document control requirement units (IO-101, Records Management, Rev. 2) ................... 27

3. DOE-ORO ER Program and Energy Systems records management and document control requirement units (ESS-IO-201, Document Control, Rev. 2) . . . . . . . . . . . . . . 65 



\section{ACRONYMS}

$\begin{array}{ll}\text { AR } & \text { Administrative Record } \\ \text { CERCLA } & \text { Comprehensive Environmental Response, Compensation, } \\ & \text { and Liability Act of 1980 } \\ \text { ECC } & \text { Emergency Control Center } \\ \text { Energy Systems } & \text { Martin Marietta Energy Systems, Inc. } \\ \text { ER } & \text { Environmental Restoration Program } \\ \text { ERWM } & \text { Environmental Restoration Waste Management Program } \\ \text { ES\&H } & \text { Environmental Safety and Health } \\ \text { D\&D } & \text { decontaminating and decommissioning } \\ \text { DMC } & \text { document management center } \\ \text { DOE } & \text { U.S. Department of Energy } \\ \text { DOERS } & \text { U.S. Department of Energy Records Schedule } \\ \text { DQI } & \text { Data Quality Investigation } \\ \text { EOC } & \text { Emergency Operating Center } \\ \text { FRC } & \text { Federal Records Center } \\ \text { FS } & \text { feasibility study } \\ \text { FFA } & \text { Federal Facility Agreement } \\ \text { FPMR } & \text { Federal Property Management Regulation } \\ \text { GAO } & \text { General Accounting Office } \\ \text { GRS } & \text { General Records Schedule } \\ \text { IMS } & \text { Information Management Services } \\ \text { IRM } & \text { Information Resource Management (Program) } \\ \text { NARA } & \text { National Archives and Records Administration } \\ \text { ORO } & \text { Oak Ridge Operations } \\ \text { ORNL } & \text { Oak Ridge National Laboratory } \\ \text { ORR } & \text { Oak Ridge Reservation } \\ \text { OSHA } & \text { Occupational Safety and Health Administration } \\ \text { OU } & \text { operable unit } \\ \text { QA } & \text { quality assurance } \\ \text { RI } & \text { remedial investigation } \\ \text { RIDS } & \text { records inventory and dispositions schedule } \\ \text { STARR } & \text { site technical Administrative Record review } \\ \text { USC } & \text { United States Code } \\ \text { WBS } & \text { work breakdown structure } \\ \text { WM } & \text { Waste Management } \\ & \\ & \end{array}$




\section{INFORMATION RESOURCE MANAGEMENT BACKGROUND}

\subsection{DOCUMENT PURPOSE}

The purpose of the Environmental Restoration Information Resources Management (ER IRM) Program Plan is to define program requirements, organizational structures and responsibilities, and work breakdown structure (WBS) and to establish an approved baseline against which overall progress of the program as well as the effectiveness of its management will be measured. This plan will guide ER IRM Program execution and define the program's essential elements. This plan will be routinely updated to incorporate key decisions and programmatic changes and will serve as the project baseline document. Environmental Restoration Waste Management (ERWM) Program intersite procedures and work instructions will be developed to facilitate the implementation of this plan.

\subsection{SCOPE}

The scope of this activity includes the management and the coordination of records management and document control and Administrative Record (AR) activities by (1) Martin Marietta Energy Systems, Inc. (Energy Systems), (2) U.S. Department of Energy (DOE ) Oak Ridge Operations (ORO) ER Division, and (3) associated DOE-ORO prime contractors. This pertains to all records generated or received by or for the DOE-ORO ER Program in support of ER-funded activities performed at the Oak Ridge Reservation (ORR)-Oak Ridge K-25 Site; Oak Ridge National Laboratory (ORNL); Oak Ridge Y-12 Plant; Portsmouth and Paducah gaseous diffusion plants; and off-site areas adjacent to the Oak Ridge facilities referred to as the ORR off site area. These records are generated by Energy Systems, DOEORO ER Program, DOE-ORO ER prime contractors, and subcontractors. A record is defined to include all books, papers, maps, photographs, machine-readable materials, or other documentary materials regardless of physical forms or characteristics, which are made or received by an agency of the U.S Government. Records are protected by federal law or in connection with the transaction of public business and are preserved or can be preserved by the agency or its legitimate successor as evidence of the organization, functions, policies, decisions, procedures, operations, or other activities of the government.

\subsection{MISSION STATEMENT}

The mission of the ER IRM Program is to establish an integrated, compliant, and cost effective information management system from a single multisite platform in support of DOEORO ER Program remediation activities. 


\subsection{PROGRAM GOALS AND TECHNICAL OBJECTIVE}

The following are the programmatic goals of the ER IRM Program:

- establish and maintain legally defensible ARs;

- develop a compliant records management and document control system;

- establish document management centers that provide access to ER records throughout their life cycle;

- develop specific ER project file methodologies in support of ER activities;

- as integrating contractor, ensure standard implementation of $A R$ and records management and document control requirements;

- develop and implement a comprehensive DOE-ORO ER information management system establishing Energy Systems as the record copy holder for all DOE-ORO ER Program records.

The technical objective of the ER IRM Program is to serve as a center of excellence in the development, implementation, and management of compliant and economically sound ER records management and document control systems. In addition to meeting all regulatory requirements, records generated by or for the ER Program must be converted to a userfriendly information resource platform and be available to ER project managers and personnel as a tool to more effectively manage ER work. To effectively support the ER Program, the ER IRM must remain current with the dynamic operational, regulatory, and technical ER multisite and multicontractor program activities. This will be accomplished through the use of dedicated project management with an emphasis on the best management practices, teamwork, and customer satisfaction. 


\section{INFORMATION RESOURCE MANAGEMENT DESCRIPTION}

\section{RECORDS MANAGEMENT PROGRAM RISK ASSESSMENT}

Certain potential program risks must be addressed and resolved to ensure achievement of the mission and goals (Sects 1.3 and 1.4). These risks and the proactive measures the ER IRM Program will take to address these concerns are listed below.

- Noncompliance with records storage requirements-Utilize newly acquired space to provide dual storage in a graded approach, and actively pursue alternate storage mediums.

- Lack of ER Program confidence and cooperation-Demonstrate program ability to accomplish defined goals and provide diligent, effective, and responsive attention to ER Program needs.

- Lack of operational consistency between ER site programs-Ensure procedures developed are at a standard implementation level and actively support integration of site activities.

- Impacts of unforeseen corporate initiatives such as the ERWM integration, "Reinventing Martin Marietta, "and the current reduction in force-Establish an ongoing awareness and process to evaluate and address programmatic impacts of potential corporate initiatives and flowdown requirements.

\section{ORGANIZATION, ROLES, AND RESPONSIBILITIES}

\section{Organizational Components}

The ER IRM Program is comprised of three key components: AR management; document control and records management; and information systems management. The ER IRM Program manager reports to the ER Compliance and Risk Integration manager who reports to the ER director. Figure 1 illustrates the ER IRM Program's organizational structure. Figure 2 demonstrates the reporting line within the ER Program.

\section{Roles and Responsibilities}

The ER IRM Program manager directs, coordinates, and administers the budgeting, development, application, implementation, and oversight of ER IRM Program activities and staff. The ER IRM Program manager must integrate Energy Systems with ER Program and site program-specific records requirements and applications. The following are area managers reporting to the ER IRM Program.

- AR manager as lead integrating contractor, provides technical and practical interpretation of the National Contingency Plan/Comprehensive Environmental Response, Compensation, and Liability Act (CERCLA), as it pertains to the AR to ensure compliant and standardized compilation. This manager also develops and maintains standards and procedures required to ensure the same; provides oversight responsibility for Portsmouth and Paducah; and manages staff in the accomplishment of these tasks. 


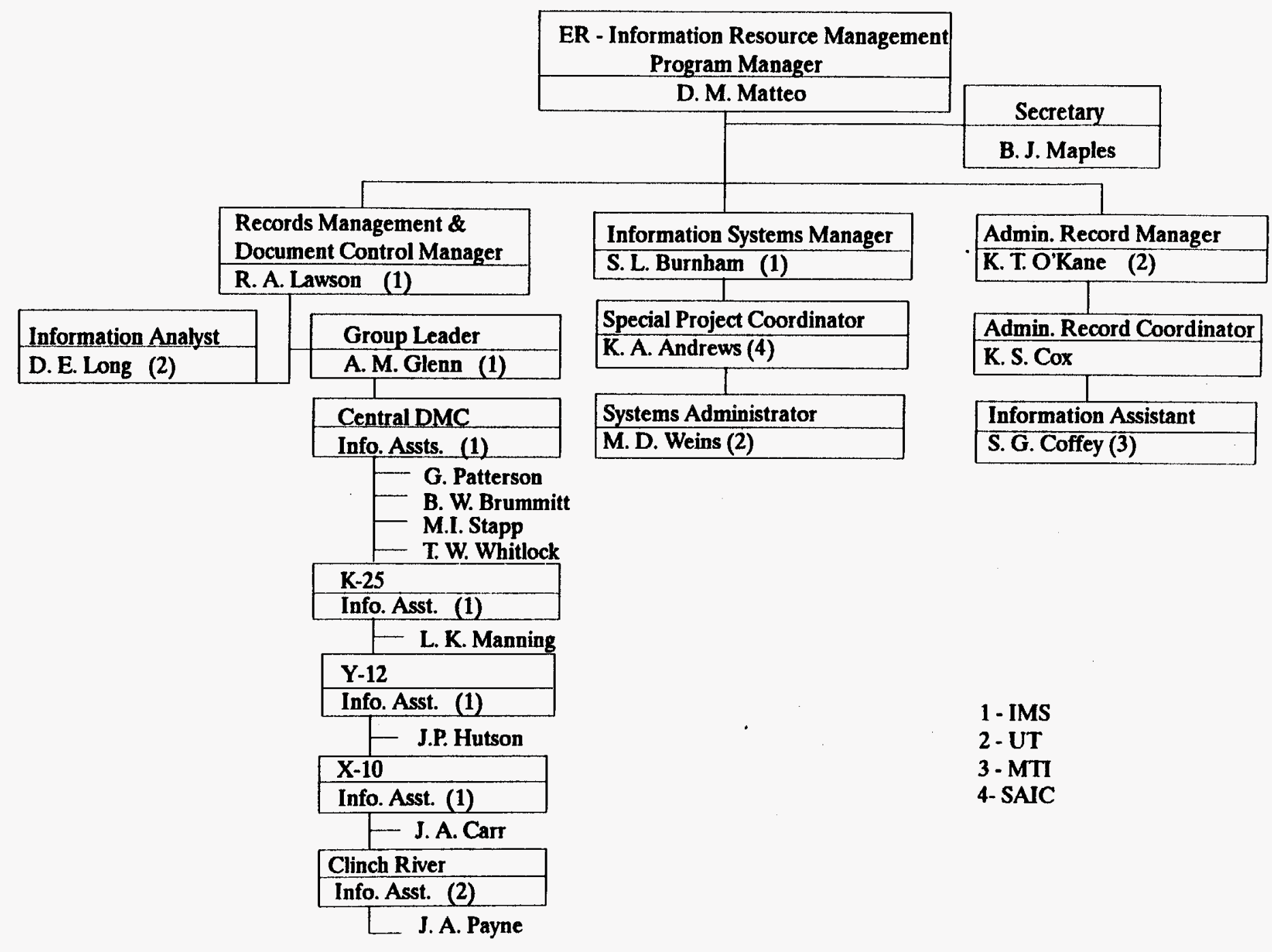

Fig. 1. Environmental Restoration Information Resource Management Program organization chart. 


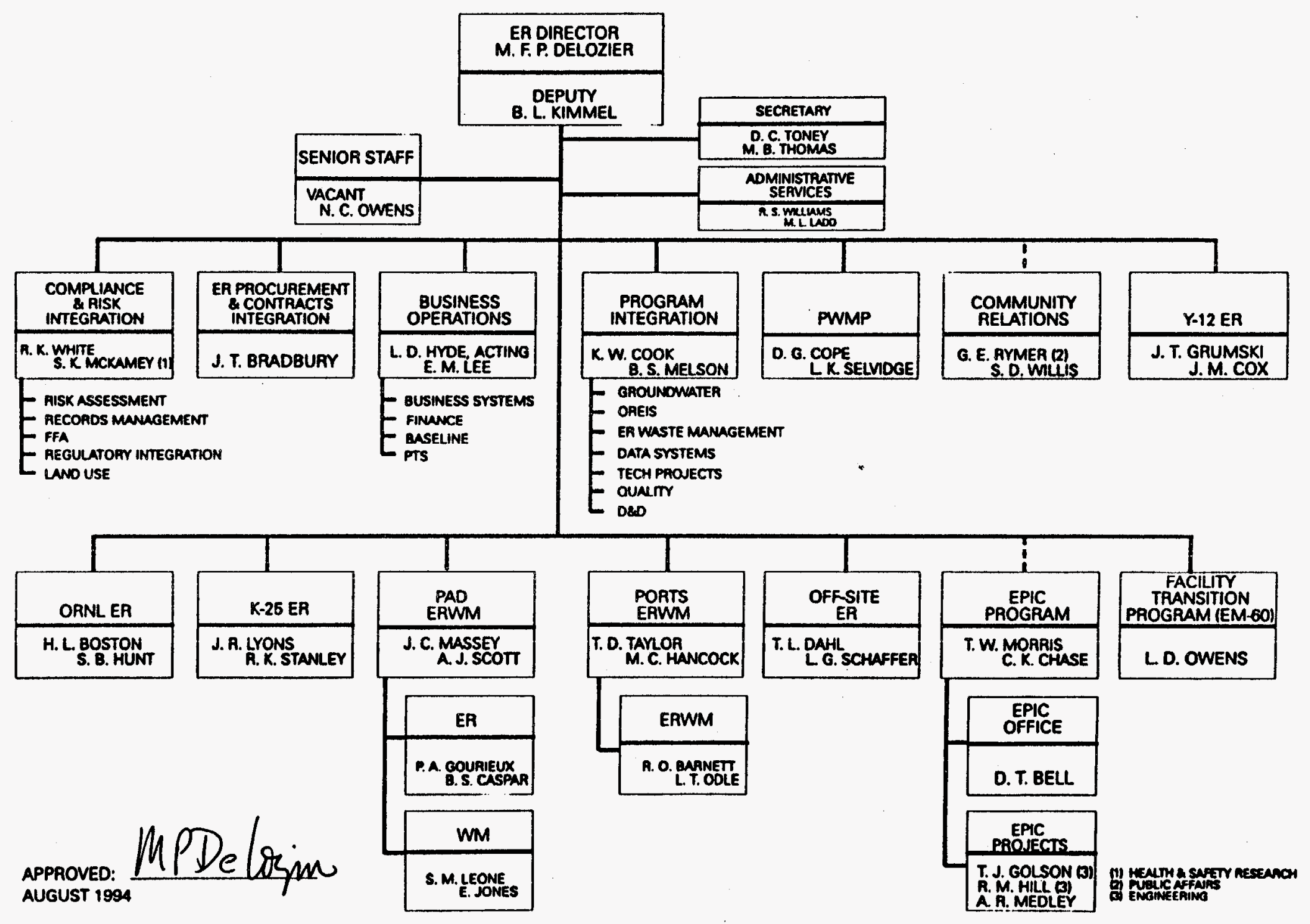

Fig. 2. Environmental Restoration Program organization chart. 
- Records Management and Document Control manager develops and implements a records management and document control system based on flowdown requirements defined in Energy Systems Procedures IO-101 and 201 to manage ER record copies. This manager coordinates with both Energy Systems and ERWM divisional records management to integrate all statutory, DOE, and Energy Systems records management policies into ER; manages and operates the ER Central Document Management Center (DMC) and satellites; develops ER specific records requirements such as CERCLA and D\&D specific project file criteria; and manages staff in the accomplishment of these tasks.

Information Management Services (IMS) provides personnel with records experience to develop the records management and document control systems and operate the document management centers. As illustrated in Fig. 1, IMS is a matrix organization that will provide the Records Management and Document Control manager, DMC group leader, and nine information assistants to staff the central and satellite DMCs.

- Information Systems manager formulates ER IRM information management policies, procedures, and automated systems requirements and ensures integration into records management and document control systems. This manager interprets and ensures adherence to DOE and Energy Systems guidance related to the management of electronic information; manages development and implementation of a comprehensive distributed electronic information system that supports DOE-ORO ER activities for Energy Systems and their associated prime contractors; provides oversight responsibility for related Paducah and Portsmouth activities; and is responsible for the administration and management of resources necessary in the accomplishment of these tasks.

\section{REQUIREMENTS}

Records management, document control, and AR requirement units will be documented and maintained in a programmatic compliance baseline as part of the ER Compliance Management Program. Implementing procedures will be adopted at the highest level of prescription integrated with the ERWM Compliance Management Program and charted to ensure that permitted gaps in procedural flowdown are filled with an appropriate level of instruction throughout the ER Program.

AR, records management, and document control requirements are regulatory driven and compliance must be ensured. The ER Program/site-specific requirements do not have direct regulatory drivers, but they integrate ER-specific processes granting the ER Program efficient and relevant utilization of information.

\subsection{CERCLA AR Requirements}

The CERCLA AR requirements have been summarized in Table 1 (See Appendix).

Established under Sect. 113 of CERCLA, the AR serves two primary purposes. First, under Sect. 113(j), judicial review of an issue concerning the adequacy of the response selection is limited to the contents of the AR. However, to the extent to which the agency attain the benefits of limited judicial review depends on the quality and completeness of the 
record. Second, Sect. $113(k)$ requires that the $A R$ act as a vehicle for public participation in selecting the response action and documenting that process.

An AR file will be created for each OU upon regulatory approval of a remedial investigation work plan or regulatory approval to proceed based on other criteria. Subsequent documentation, as defined by $\mathrm{AR}$ file criteria, will be included in the $A R$ file contemporaneously with the remedial or removal action work performed on that operable unit. After the Record of Decision document has been signed with appropriate signatures, a site technical AR review (STARR) meeting will be held as a final review of the AR file contents by DOE-ORO ER and all ER prime contractors. The recommended AR will be established and submitted to DOE-ORO ER for submittal for written approval to the environmental regulators.

CERCLA requires that each $A R$ file and $A R$ be maintained at two locations; a federal facility and an off-site location designated for public access. Energy Systems AR staff will initiate and designate documents for inclusion in the AR files and turn these documents over to the ER Central DMC to be retained as the on-site copy. Energy Systems AR staff will transmit a copy of all public AR file documents and other pertinent information to DOEORO ER technical support contractor staff located at the Information Resource Center, 105 Broadway, Oak Ridge, Tennessee. They will be responsible for maintaining and presenting the off-site copy to the public.

The following integrating contractor standard and procedure were developed, issued, and successfully implemented. Consistent maintenance and a continuing training program ensure AR compliance and excellence.

- Standard ER/C-S1505, Rev. 0, "Roles and Responsibilities of Martin Marietta Energy Systems, Inc., as the Integrating Contractor for the Administrative Record.” April 6, 1993.

- Procedure ER/C-P1506, Rev.0, "Martin Marietta Energy Systems, Inc., Management of the Environmental Restoration Program,” December 14, 1992.

\subsection{DOE/Energy Systems Records Management and Document Control Requirements}

DOE-ORO ER and Energy Systems Records Management and Document Control requirement units have been identified in Tables 2 and 3 (See Appendix).

Established under CFR 36, Chap. 12, National Archives and Records Management, the requirements for managing government records cover the creation, identification, maintenance, retention, and disposition of the records. To address these requirements, this program will establish a consistent work flow process for ER records. Figure 3 charts the work flow process for records originated within the Energy Systems ER Program, and Figure 4 charts the process for ER records originated outside Energy Systems ER. Procedures will be developed or revised to ensure standard implementation of records management activities, including the appropriate integration of site records activities. To facilitate program compliance and to more effectively utilize current resources, a graded approach methodology will be applied to program development and implementation. Training will be developed and updated as required to provide ER personnel with the knowledge and skills necessary to 


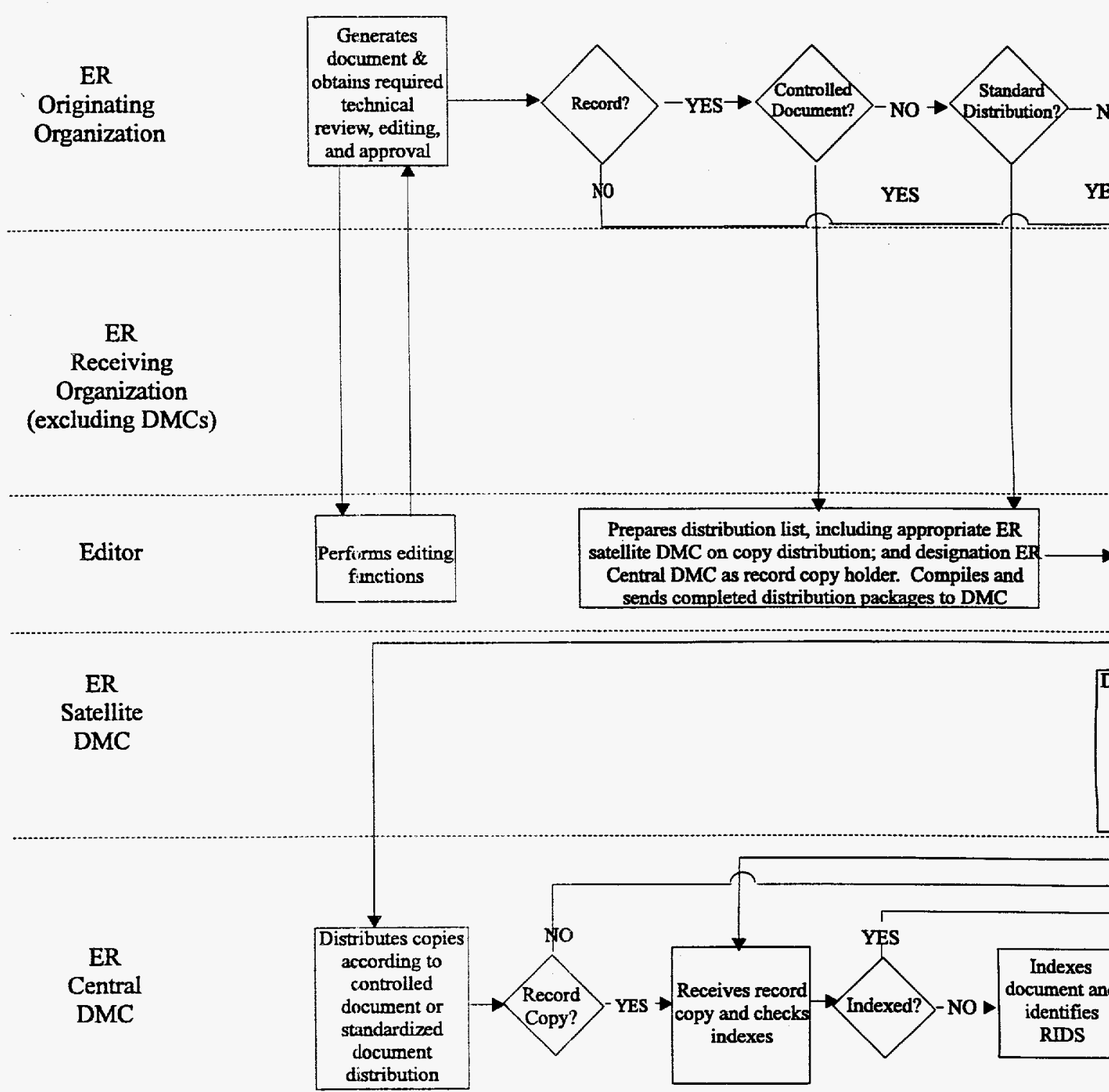

\section{Administrative \\ Record \\ Staff}

flolr8.cot Seprember 22, 1994

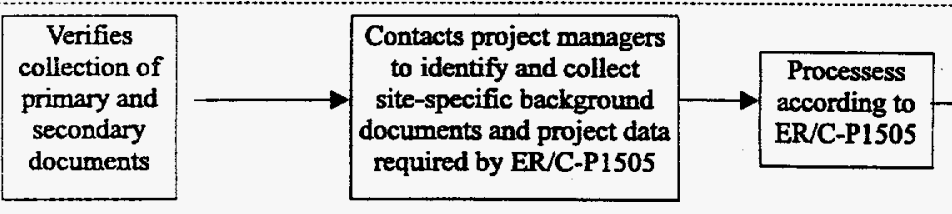

Fig 3. Work flow process for 


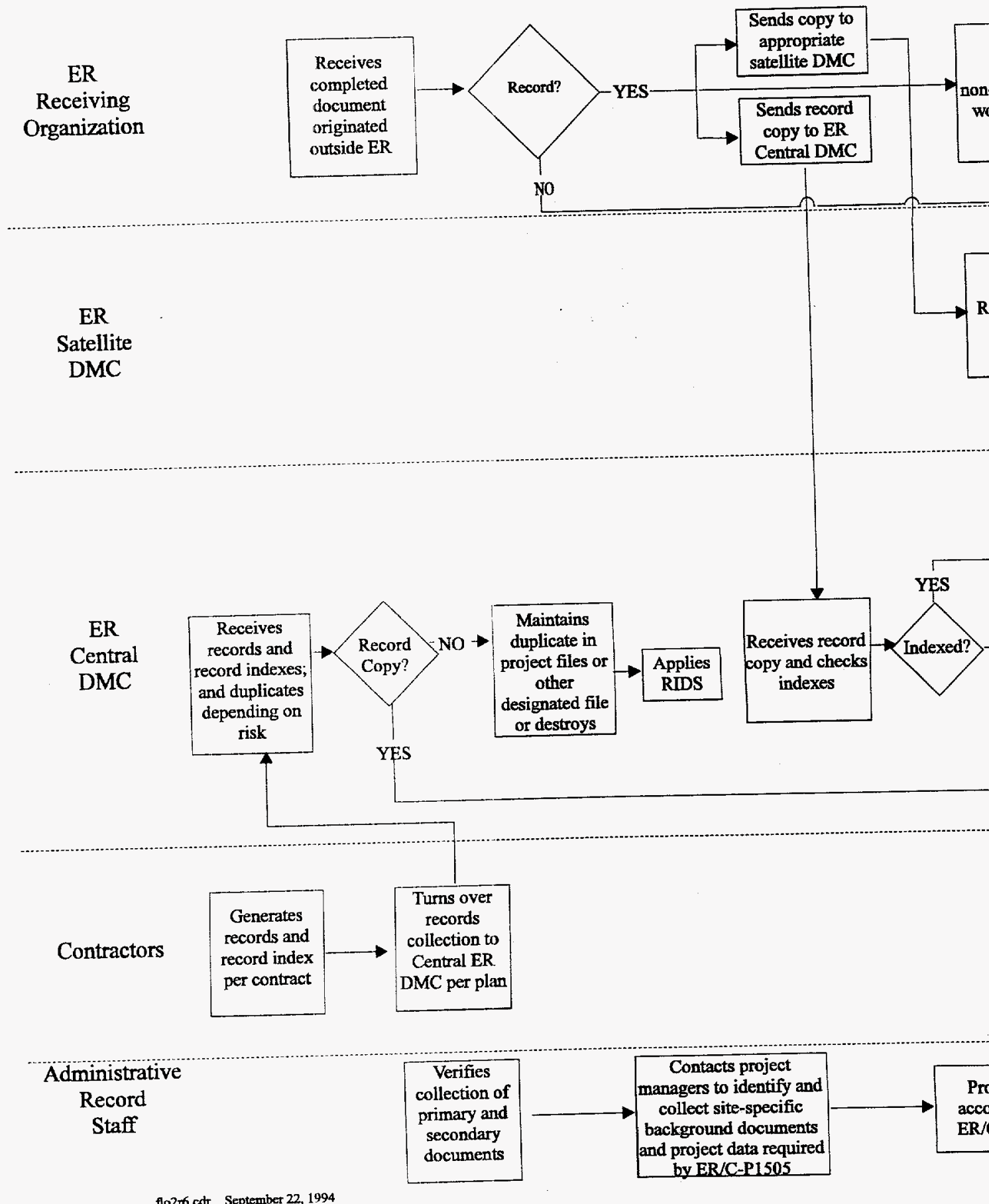

Fig. 4. Work flow proc 
maintain a successful and standardized records management program. A self-assessment module will be developed to ensure adherence to ER records management policies and procedures. Combined, these activities will ensure the capture and maintenance of ER records and will provide the platform for a comprehensive electronic information system proposed for the ER Program.

The ER Central DMC serves as the hub of all ER records activities and will house the official record copy of ER-generated/sponsored materials. Building K-1002 is currently under renovation and will provide $7000 \mathrm{sq} \mathrm{ft}$ of records storage and work space. The ER Central DMC has established satellite centers to provide project files that are accessible to project personnel and to assist in capturing project-specific records. Currently, satellite centers support each of the following ER programs: the K-25 Site, the Y-12 Plant, ORNL, Clinch River, and the Ponds Waste Management Program. The central and satellite DMCs are in the process of becoming a network. In preparation for this network, the DMCs are currently indexing record backlogs, cleaning up databases, and performing shelf-to-index inventories. The ER Central DMC facility is not fully in compliance with the stringent NQA-1, Supplement 17S-1, which are single record copy storage requirements. However, until the implementation of a storage medium other than paper, the project file copy maintained at the satellite centers will comply with the dual record storage option. Additionally, a quality assurance (QA) records system will be designed, implemented, and enforced. To avoid duplication of effort, QA records will be defined as ER required records. The following are other issues currently being addressed:

- development of a standard and controlled documents distribution;

- development of a D\&D records management system; and

- development of CERCLA and D\&D project file guides.

\subsubsection{ER Program/Site Specific Requirements}

ER Program and site-specific requirements are not regulatory driven but critical to the successful implementation of the ER IRM Program. ER IRM must have the capability to store and retrieve program- and site-specific information in a variety of formats to enable ER personnel to meet reporting requirements. This will be accomplished through by utilizing an information management system that provides accurate, timely information needed to support decision making processes. This program area must stay abreast of ER Program developments and implement systems that are flexible enough to meet program requirements as functions and priorities evolve over time. 


\section{INFORMATION RESOURCE MANAGEMENT FY 1995 WORK PLAN}

\subsection{BACKGROUND}

The ER IRM was chartered in April 1993 to consolidate all DOE-ORO ER records activities and more effectively and efficiently manage the records associated with ER operations. It was determined that AR activities, previously under the FFA implementation group, would also be merged with this program. The $A R$ is a mature program recognized favorably by DOE-ORO and the regulatory community, and operational excellence will be maintained. However, the immediate program emphasis will focus on developing records and information management systems.

The concept of a single records and information system supporting all DOE-ORO ER records activities is a challenging task. A logical implementation strategy was developed based on process development, implementation requirements, and priority of the tasks. Development of a model Energy Systems ER Program records management and document control system and supporting procedures has been identified as the top priority. Successful completion of this task would position Energy Systems, integrating contractor, to issue standard guidance to subcontractors and other DOE-ORO ER prime contractors. While developing this model, investigations will begin to define requirements for and identify an electronic information system to effectively process the records produced by the ER Program, validate our past operations, and provide a management tool for ER personnel today and in the future.

\subsection{ACCOMPLISHMENTS}

Since program creation and the development of this program plan, implementation of the ER IRM Program has significantly progressed. To date, the ER IRM Program has accomplished the following:

- developed a management system organizational infrastructure;

- developed roles and responsibilities and job descriptions;

- consolidated ER records management activities;

- received favorable DOE-ORO ER Program review (August 1993);

- developed the draft CERCLA Project File Guide;

- implemented $90 \%$ of DMC networking;

- completed DOE records inventory of all ER Program records;

- initiated the investigation of a cradle-to-grave electronic information management system;

- established support services Memorandum of Understanding with former Information Services Division;

- acquired K-1002 building ( $7000 \mathrm{sq} \mathrm{ft}$ ) for ER Central DMC operations; 
- revised Chap. 4, "Documents and Records," of the ER Quality Program Plan, ES/ER/TM-4/R4, to reflect current operations.

\subsection{FY 1995 TASKS}

Listed below are actions scheduled for development and implementation in FY 1995. Completion of these tasks will establish the framework for a comprehensive records management program. These actions have been integrated with the DOE-ORO Data Quality Investigation (DQI) initiative and were approved by the DQI Steering Committee in August 1994.

- Issue an ER IRM Program plan which documents requirements, organizational structures, roles and responsibilities, WBS, and established a baseline against which overall performance shall be measured. Scheduled completion date: September 30, 1994.

- Establish a records management and document control programmatic compliance baseline of requirements by functional area, and integrate ER IRM organizational infrastructure with the ER requirements flowdown system and the ERWM Compliance Management Program. The scheduled completion date is March 3, 1995.

- Develop program level implementation procedures as defined in the requirements flowdown assessment and document acceptance of/exemption from any requirement units. The scheduled completion date is December 30, 1994.

- Develop system requirements documentation and perform vendor analysis on electronic work flow software available to electronically manage ER records throughout their life cycle. The scheduled completion date is March 15, 1995.

- Establish a training module that schedules and documents training required for and administered to records, site, subcontractor, and prime contractor personnel. The scheduled completion date is June 30, 1995.

- Establish an assessment module that ensures and documents compliance with ER functional record procedures and requirements. The scheduled completion date is September 30, 1995.

- Develop and issue an ER integrating contractor standard extending ER records management and document control requirements to all DOE-ORO ER prime contractors. The scheduled completion date is April 21, 1996.

\subsection{SCHEDULES AND MILESTONES}

AR activities are initiated and scheduled according to the negotiated regulatory milestones documented in the FFA, Appendix E. Deliverables associated with the records management and document control area are detailed in Sect. 3.3. of this plan. 


\subsection{TECHNICAL PERFORMANCE CRITERIA}

Technical performance criteria used to assess regulatory performance of ER IRM activities are outlined in Sect. 2.3 of this plan. Section 3.3 provides key performance measures for assessing the effectiveness of this program. In addition, overall DOE-ORO ER and ER Program customer satisfaction also serve as critical technical performance criteria.

\subsection{INFORMATION AND REPORTING}

Information concerning the current status, schedules, activities, or budget of the ER IRM Program can be obtained by contacting the ER IRM program manager. The ER IRM submits weekly highlights to the ER Program, provides input to the FFA quarterly report, and prepares and submits all required budgetary documentation under the management system. 


\section{WORK BREAKDOWN STRUCTURE}

Figure 5 illustrates the WBS chart for the ER IRM Program under activity data sheet 8304 .

The comprehensive WBS for the ER IRM will serve as the framework for planning, assignment of responsibilities, technical baseline, schedule control, cost summaries, and change control. The ER IRM Program management levels listed below provide a logical summary point for assessing technical accomplishments, identifying the funding requirements, and measuring cost and schedule performance.

- Administrative Record,

- Program Administration,

- Information Systems,

- Records Management and Document Control, and

- Central DMC Operations.

\subsection{ADMINISTRATIVE RECORD-1.4.123.04.14.01}

This activity provides for the management and coordination of AR requirements and activities established in the above specified procedures to ensure compliant and consistent implementation of ARs and AR files. The AR staff develops and updates AR file criteria; establishes $\mathrm{AR}$ files as required and contemporaneously assigns materials for inclusion into on-site AR files; verifies or coordinates document clearance; provides basic indexing information; properly labels and transmits appropriate AR file materials to the off-site AR file managed by the DOE technical support contractor for public review; coordinates STARR meetings; and ensures AR finalization and protection.

\subsection{PROGRAM ADMINISTRATION-1.4.1223.04.14.02}

This activity administers overall program management and direction and coordination for technical consistency of strategy and methodologies used to address ER IRM activities. This activity develops short- and long-range plans and associated budget proposals; interacts with senior management, DOE, and regulatory agencies for communication of technical information; develops budgets, including current year work plans and baselines; tracks progress and evaluation; analyzes variance and reporting; attends ER, Compliance and Risk Integration, and DOE meetings; maintains staffing resource requirements; and prioritizes work.

\subsection{INFORMATION SYSTEMS-1.4.1223.0.14.03}

This activity tracks the development of system requirements, analysis of technology solutions, and pilot and full-scale implementation of automated systems that manage 


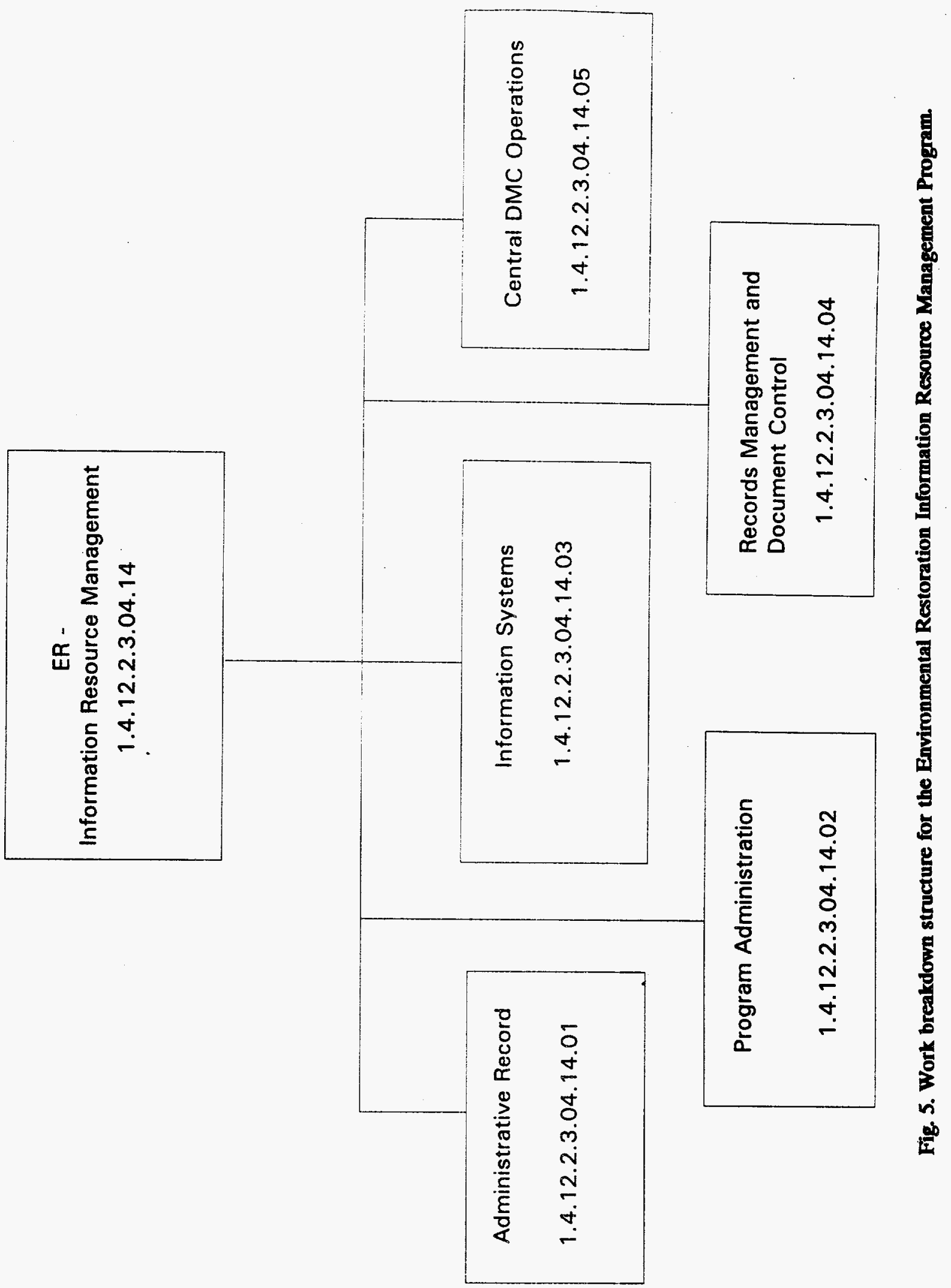


Program information from "cradle to grave;" ensures that automated information systems are designed to meet program recordkeeping requirements by defining and reviewing requirements; and provides platform for comprehensive DOE-ORO ER records system.

\subsection{RECORDS MANAGEMENT AND DOCUMENT CONTROL- 1.4.1223.04.14.04}

This activity provides for the development of a records management and document control system and the appropriate implementation procedures for ER records based on established flowdown requirements; ensures compliance and integration to Energy Systems divisional records policies; establishes document centers to both capture and make accessible ER records throughout their life cycle.

\subsection{CENTRAL DMC OPERATIONS-1.4.12.23.04.14.05}

This activity provides for the centralized maintenance of ER record copies to include indexing, storage, control, and retrieval of records; serves as focal point of satellite activities; maintains ER controlled documents in the Controlled Document Management System; performs distribution of ER documents and reports; participates in and responds to audits. 


\section{APPENDIX \\ Information Resource Management Program Plan Tables 1 through 3}



Table 1. CERCLA Administrative Record requirements

\begin{tabular}{|c|c|c|c|c|}
\hline \multicolumn{4}{|c|}{ Administrative and technical basis } & $\begin{array}{l}\text { Administrative Record } \\
\text { ER/s-1505, Rev.0 (12/14/92) and } \\
\text { ER/P-1506, Rev. } 0 \text { (04/06/93) }\end{array}$ \\
\hline Requirement document & \multicolumn{2}{|c|}{ Section/paragraph } & Flowdown status & Requirement unit \\
\hline $\begin{array}{l}40 \text { CFR 300, Subpart I - } \\
\text { Administrative Record for } \\
\text { Selection of Response Action }\end{array}$ & 300.800 & $\begin{array}{l}\text { Establishment of an } \\
\text { administrative } \\
\text { record. } \\
\text { (a) }\end{array}$ & Complete & $\begin{array}{l}\text { General Requirement. The lead agency shall establish an } \\
\text { administrative record that contains the documents that form the } \\
\text { basis for the selection of a response action. The lead agency shall } \\
\text { compile and maintain the administrative record in accordance with } \\
\text { this subpart. }\end{array}$ \\
\hline $\begin{array}{l}40 \text { CFR 300, Subpart I - } \\
\text { Administrative Record for } \\
\text { Selection of Response Action }\end{array}$ & 300.800 & $\begin{array}{l}\text { Establishment of an } \\
\text { administrative } \\
\text { record. } \\
\text { (b) }\end{array}$ & Complete & $\begin{array}{l}\text { Administrative Records for federal facilities. } \\
\text { (1) If a federal agency other than EPA is the lead agency for a } \\
\text { federal facility, the federal agency shall compile and maintain the } \\
\text { administrative record for the selection of the response action for } \\
\text { that facility in accordance with this subpart. EPA may furnish } \\
\text { documents which the federal agency shall place in the } \\
\text { administrative record file to ensure that the administrative record } \\
\text { includes all documents that form the basis for the selection of the } \\
\text { response action. } \\
\text { (2) EPA or the U.S. Coast Guard shall compile and maintain the } \\
\text { administrative record when it is the lead agency for a federal } \\
\text { facility. } \\
\text { (3) If EPA is involved in the selection of the response action at a } \\
\text { federal facility on the National Priorities List, the federal agency } \\
\text { acting as the lead agency shall provide EPA with a copy of the } \\
\text { index of documents included in the administrative record file, the } \\
\text { RI/FS (remedial investigation/feasibility study) work plan, the } \\
\text { RI/FS released for public comment, the proposed plan, and public } \\
\text { comments received on the RI/FS and proposed plan, and any } \\
\text { other documents EPA may request on a case-by-case basis. }\end{array}$ \\
\hline
\end{tabular}


Table 1 (continued)

\begin{tabular}{|c|c|c|c|}
\hline \multicolumn{3}{|c|}{ Administrative and technical basis } & $\begin{array}{l}\text { Administrative Record } \\
\text { ERS-1505, Rev.0 (12/14/92) and } \\
\text { ER/P-1506, Rev. 0 (04/06/93) }\end{array}$ \\
\hline Requirement document & Section/paragraph & Flowdown status & Requirement unit \\
\hline $\begin{array}{l}40 \text { CFR 300, Subpart I - } \\
\text { Administrative Record for } \\
\text { Selection of Response Action }\end{array}$ & $\begin{array}{l}\text { 300.800 Establishment of an } \\
\text { administrative } \\
\text { record. }\end{array}$ & Complete & $\begin{array}{l}\text { Administrative record for state-lead sites. If a state is the lead } \\
\text { agency for a site, the state shall compile and maintain the } \\
\text { administrative record for the selection of the response action for } \\
\text { that site in accordance with this subpart. The state shall provide } \\
\text { EPA with a copy of the index of documents included in the } \\
\text { administrative record file, the RI/FS work plan, the RI/FS } \\
\text { released for public comment, the proposed plan, any public } \\
\text { comments received on the RI/FS and proposed plan, and any } \\
\text { other documents EPA may request on the case-by-case basis. }\end{array}$ \\
\hline $\begin{array}{l}40 \text { CFR 300, Subpart I - } \\
\text { Administrative Record for } \\
\text { Selection of Response Action }\end{array}$ & $\begin{array}{l}300.800 \text { Establishment of an } \\
\text { administrative record. } \\
\text { Paragraph (e) }\end{array}$ & Complete & $\begin{array}{l}\text { For those response actions not included in paragraph (d) of this } \\
\text { section, the lead agency shall comply with this subpart to the } \\
\text { extent practicable. }\end{array}$ \\
\hline $\begin{array}{l}40 \text { CFR 300, Subpart I - } \\
\text { Administrative Record for } \\
\text { Selection of Response Action }\end{array}$ & $\begin{array}{l}\text { 300.805 Establishment of an } \\
\text { administrative record. } \\
\text { Paragraph (a) }\end{array}$ & Complete & $\begin{array}{l}\text { The lead agency shall establish a docket at an office of the lead } \\
\text { agency or other central location at which documents included in } \\
\text { the administrative record file shall be located and a copy of the } \\
\text { documents included in the administrative record file shall also be } \\
\text { made available for public inspection at or near the site at issue, } \\
\text { except as provided below: } \\
\text { (4) Documents included in the confidential portion of the } \\
\text { administrative record file shall be located only in the central } \\
\text { location. }\end{array}$ \\
\hline $\begin{array}{l}40 \text { CFR 300, Subpart I - } \\
\text { Administrative Record for } \\
\text { Selection of Response Action }\end{array}$ & $\begin{array}{l}300.805 \text { Location of the } \\
\text { administrative record } \\
\text { file. } \\
\text { Paragraph (b) }\end{array}$ & Complete & $\begin{array}{l}\text { Where documents are placed in the central location but not in the } \\
\text { file located at or near the site, such documents shall be added to } \\
\text { the file located at or near the site upon request, except for } \\
\text { documents included in paragraph (a)(4) of this section. }\end{array}$ \\
\hline
\end{tabular}


Table 1 (continued)

\begin{tabular}{|c|c|c|c|}
\hline \multicolumn{3}{|c|}{ Administrative and technical basis } & $\begin{array}{l}\text { Administrative Record } \\
\text { ER/S-1505, Rev.0 (12/14/92) and } \\
\text { ER/P-1506, Rev. 0 (04/06/93) }\end{array}$ \\
\hline Requirement document & Section/paragraph & Flowdown status & Requirement unit \\
\hline $\begin{array}{l}40 \text { CFR 300, Subpart I - } \\
\text { Administrative Record for } \\
\text { Selection of Response Action }\end{array}$ & $\begin{array}{l}300.810 \text { Contents of the } \\
\text { administrative record } \\
\text { file. }\end{array}$ & Complete & $\begin{array}{l}\text { Contents. The administrative record file for selection of a response } \\
\text { action typicalty, but not in all cases, will contain the following types } \\
\text { of documents: } \\
\text { (1) Documents containing factual information, data and analysis } \\
\text { of the factual information, and data that may form a basis for the } \\
\text { selection of the response action.... } \\
\text { (2) Guidance documents, technical literature, and site-specific } \\
\text { policy memoranda that may form a basis for the selection of the } \\
\text { response action.... } \\
\text { (3) Documents received, published, or made available to the } \\
\text { public under } \$ 300.815 \text { for remedial actions, or } \$ 300.820 \text { for } \\
\text { removal actions... } \\
\text { (4) Decision documents... } \\
\text { (5) Enforcement orders.... } \\
\text { (6) An index of the documents inciuded in the administrative } \\
\text { record file... }\end{array}$ \\
\hline $\begin{array}{l}40 \text { CFR } 300 \text {, Subpart I- } \\
\text { Administrative Record for } \\
\text { Selection of Response Action }\end{array}$ & $\begin{array}{l}300.810 \text { Contents of the } \\
\text { administrative record file. } \\
\text { Paragraph (b), 1st Sentence }\end{array}$ & Complete & $\begin{array}{l}\text { Documents not included in the administrative record file. The lead } \\
\text { agency is not required to include documents in the administrative } \\
\text { record file which do not form a basis for the selection of the } \\
\text { response action. }\end{array}$ \\
\hline $\begin{array}{l}40 \text { CFR 300, Subpart I - } \\
\text { Administrative Record for } \\
\text { Selection of Response Action }\end{array}$ & $\begin{array}{l}300.810 \text { Contents of the } \\
\text { administrative record file. } \\
\text { Paragraph (c), 1st Sentence }\end{array}$ & Complete & $\begin{array}{l}\text { Privileged documents. Privileged documents shall not be included } \\
\text { in the record file except as provided in paragraph (d) of this } \\
\text { section or where such privilege is waived. }\end{array}$ \\
\hline
\end{tabular}


Table 1 (continued)

\begin{tabular}{|c|c|c|c|c|}
\hline \multicolumn{4}{|c|}{ Administrative and technical basis } & $\begin{array}{l}\text { Administrative Record } \\
\text { ERS-1505, Rev.0 (12/14/92) and } \\
\text { ER/P-1506, Rev. O (04/06/93) }\end{array}$ \\
\hline Requirement document & \multicolumn{2}{|c|}{ Section/paragraph } & Flowdown status & Requirement unit \\
\hline $\begin{array}{l}40 \mathrm{CFR} 300 \text {, Subpart I - } \\
\text { Administrative Record for } \\
\text { Selection of Response Action }\end{array}$ & $\begin{array}{l}300.810 \\
\text { Paragraph }\end{array}$ & $\begin{array}{l}\text { Contents of the } \\
\text { administrative record } \\
\text { file. } \\
\text { (d) }\end{array}$ & Complete & $\begin{array}{l}\text { Confidential file. If information which forms the basis for the } \\
\text { selection of a response action is included only in a document } \\
\text { containing confidential or privileged information and is not } \\
\text { otherwise available to the public, the information, to the extent } \\
\text { feasible, shall be summarized in such a way as to make it } \\
\text { disclosable and the summary shall be placed in the publicly } \\
\text { available portion of the administrative record file. The confidential } \\
\text { or privileged document itself shall be placed in the confidential } \\
\text { portion of the administrative record file. If information, such as } \\
\text { confidential business information, cannot be summarized in a } \\
\text { disclosable manner, the information shall be placed only in the } \\
\text { confidential portion of the administrative record file. All } \\
\text { documents contained in the confidential portion of the } \\
\text { administrative record file shall be listed in the index to the file. }\end{array}$ \\
\hline $\begin{array}{l}40 \text { CFR } 300 \text {, Subpart I - } \\
\text { Administrative Record for } \\
\text { Selection of Response Action }\end{array}$ & $\begin{array}{l}300.815 \\
\text { Paragraph }\end{array}$ & $\begin{array}{l}\text { Administrative } \\
\text { record file for a } \\
\text { remedial action. } \\
\text { (a) }\end{array}$ & Complete & $\begin{array}{l}\text { The administrative record file for the selection of a remedial } \\
\text { action shall be made available for public inspection at the } \\
\text { commencement of the remedial investigation phase. At such time, } \\
\text { the lead agency shall publish in a major local newspaper of } \\
\text { general circulation a notice of the availability of the administrative } \\
\text { record file. }\end{array}$ \\
\hline $\begin{array}{l}40 \text { CFR 300, Subpart I - } \\
\text { Administrative Record for } \\
\text { Selection of Response Action }\end{array}$ & $\begin{array}{l}300.815 \\
\text { Paragraph } \\
\text { 1st and } 3 r\end{array}$ & $\begin{array}{l}\text { Administrative } \\
\text { record file for a } \\
\text { remedial action. } \\
\text { (b), } \\
\text { S Sentences }\end{array}$ & Complete & $\begin{array}{l}\text { The lead agency shall provide a pubic comment period as } \\
\text { specified in } 8300.430(f)(3) \text { so that interested persons may submit } \\
\text { comments on the selection of the remedial action for inclusion in } \\
\text { the administrative record file. A written response to significant } \\
\text { comments submitted during the public comment period shall be } \\
\text { included in the administrative record file. }\end{array}$ \\
\hline
\end{tabular}


Table 1 (continued)

\begin{tabular}{|c|c|c|c|}
\hline \multicolumn{3}{|c|}{ Administrative and technical besis } & $\begin{array}{l}\text { Administrative Recond } \\
\text { ER/S-1505, Rev.0 (12/14/92) and } \\
\text { ER/P-1506, Rev. } 0 \text { (04/06/93) }\end{array}$ \\
\hline Requirement document & Section/paragraph & Flowdown status & Requirement unit \\
\hline $\begin{array}{l}40 \text { CFR 300, Subpart I - } \\
\text { Administrative Record for } \\
\text { Selection of Response Action }\end{array}$ & 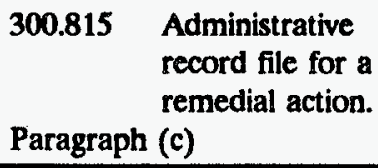 & Complete & $\begin{array}{l}\text { The lead agency shall comply with the public participation } \\
\text { procedures required in } 8300.430(f)(3) \text { and shall document such } \\
\text { compliance in the administrative record. }\end{array}$ \\
\hline $\begin{array}{l}40 \text { CFR 300, Subpart I - } \\
\text { Administrative Record for } \\
\text { Selection of Response Action }\end{array}$ & 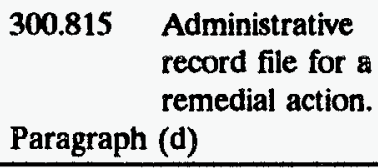 & Complete & $\begin{array}{l}\text { Documents generated or received after the record of decision is } \\
\text { signed shall be added to the administrative record file only as } \\
\text { provided in } \$ 300.825 \text {. }\end{array}$ \\
\hline $\begin{array}{l}40 \text { CFR 300, Subpart I - } \\
\text { Administrative Record for } \\
\text { Selection of Response Action }\end{array}$ & 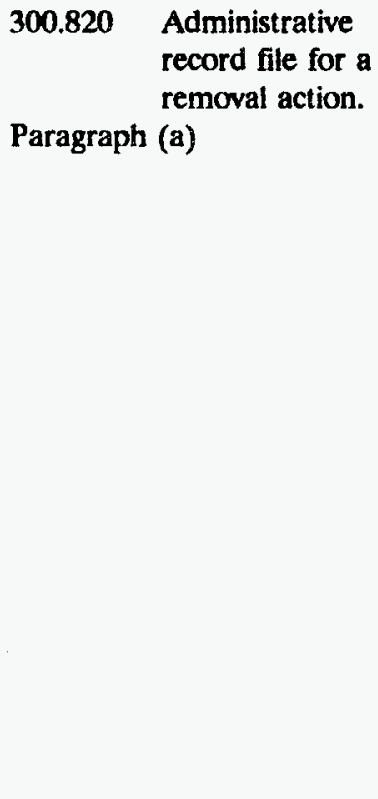 & Complete & $\begin{array}{l}\text { If, based on the site evaluation, the lead agency determines that a } \\
\text { removal action is appropriate and that a planning period of at } \\
\text { least six months exists before on-site removal activities must be } \\
\text { initiated: } \\
\text { (1) The administrative record file shall be made available for } \\
\text { public inspection when the engineering evaluation/cost analysis is } \\
\text { made available for public comment. At such time, the lead agency } \\
\text { shall public in a major local newspaper of general circulation a } \\
\text { notice of the availability of the administrative record file. } \\
\text { (2) The lead agency shall provide a public comment period as } \\
\text { specified in } \$ 300.415 \text { so that interested persons may submit } \\
\text { comments on the selection of the removal action for inclusion in } \\
\text { the administrative record file... A written response to significant } \\
\text { comments submitted during the public comment period shall be } \\
\text { included in the administrative record file. } \\
\text { (3) The lead agency shall comply with the public participation } \\
\text { procedures of } \$ 300.415 \text { (m) and shall document compliance with } \\
\$ 300.415(m)(3)(i) \text { through (iii) in the administrative record file. } \\
\text { (4) Documents generated or received after the decision document } \\
\text { is signed shall be added to the administrative record file only as } \\
\text { provided in } 8300.825 \text {. }\end{array}$ \\
\hline
\end{tabular}


Table 1 (continued)

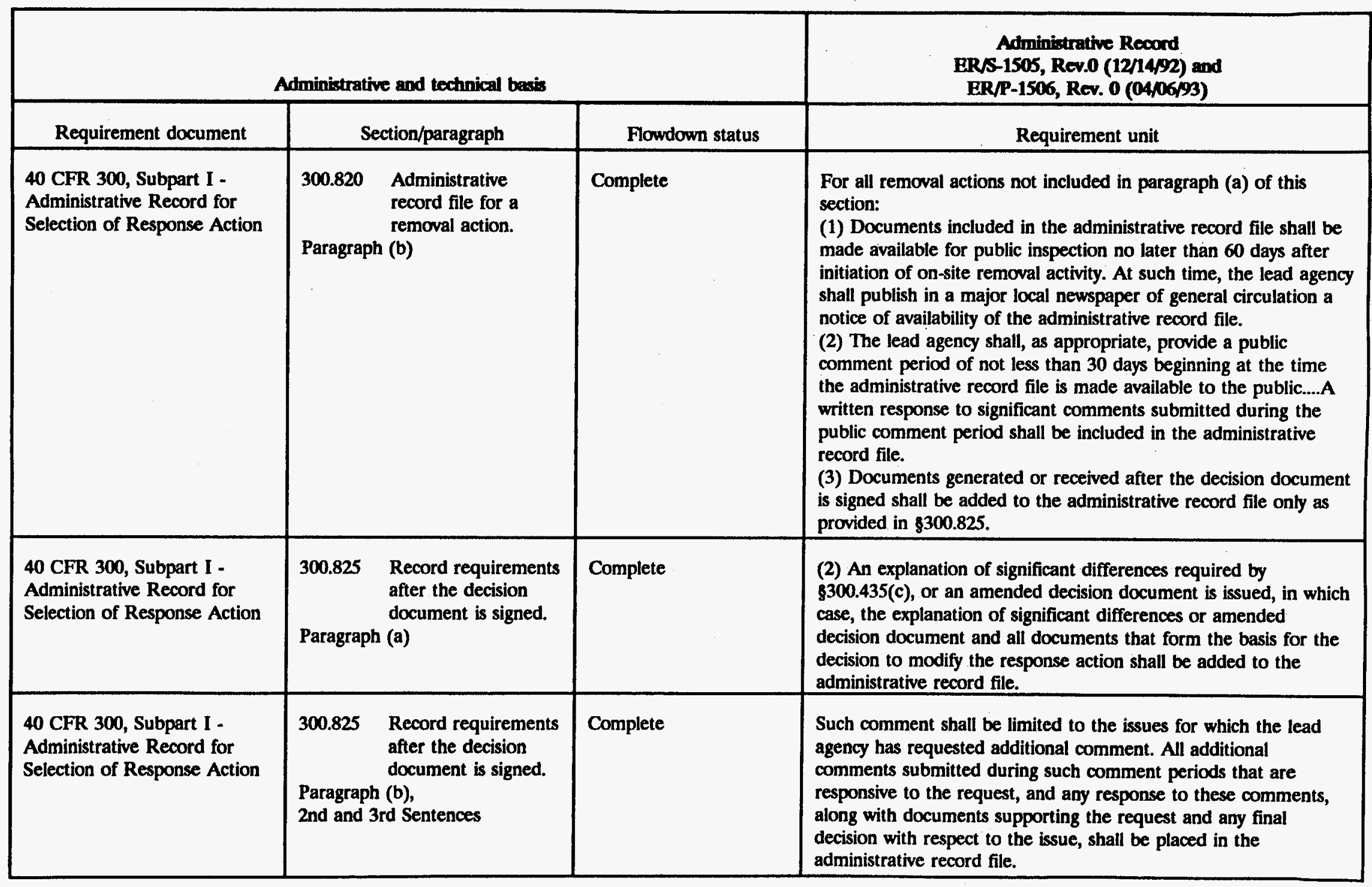


Table 1 (continued)

\begin{tabular}{|c|c|c|c|}
\hline \multicolumn{2}{|c|}{ Administrative and technical besis } & \multicolumn{1}{c|}{$\begin{array}{c}\text { Administrative Record } \\
\text { ERS-1505, Rev.0 (12/14/92) and } \\
\text { ER/P-1506, Rev. 0 (04/06/93) }\end{array}$} \\
\hline Requirement document & Section/paragraph & Flowdown status & Requirement unit \\
\hline $\begin{array}{l}\text { 40 CFR 300, Subpart 1 } \\
\text { Administrative Record for } \\
\text { Selection of Response Action }\end{array}$ & $300.825 \begin{array}{l}\text { Records } \\
\text { requirements after } \\
\text { the decision } \\
\text { document is signed. }\end{array}$ & Complete & $\begin{array}{l}\text { The lead agency required to consider comments submitted by } \\
\text { interested persons after the close of the public comment period } \\
\text { only to the extent that the comments contain significant } \\
\text { information not contained elsewhere in the administrative record } \\
\text { file which could not have been submitted during the public } \\
\text { comment period and which substantially support the need to } \\
\text { significantly alter the response action. All such comments and any } \\
\text { responses thereto shall be placed in the administrative record file. }\end{array}$ \\
\hline
\end{tabular}


Table 2. DOE-ORO ER Program and Energy Systems records management and document control requirement units (IO-101, Records Management, Rev. 2)

\begin{tabular}{|c|c|c|c|}
\hline \multicolumn{3}{|c|}{ Administrative and technical basis } & \multirow{2}{*}{$\begin{array}{l}\text { Lovel } 1 \text { document number IO-101, Reconds Management, Rev. } 2 \\
\text { Requirement unit text/comments }\end{array}$} \\
\hline Compliance document & $\begin{array}{c}\text { Level } 1 \\
\text { document section }\end{array}$ & Flowdown status & \\
\hline $\begin{array}{l}\text { DOE 1324.5A, 4/30/92 } \\
\text { Records Management Program } \\
\text { Para 8a }\end{array}$ & $\begin{array}{l}\text { Energy Systems Records } \\
\text { Manager and Site Records } \\
\text { Managers are in place. }\end{array}$ & Complete & $\begin{array}{l}\text { The site (DOE or contractor) manager will assure that a } \\
\text { management official knowiedgeable in records management policy, } \\
\text { methods, and practices is designated as the records management } \\
\text { officer. The officer may designate assistant records management } \\
\text { officers to accomplish specific responsibilities. }\end{array}$ \\
\hline 1324.5A, Para 8b (1) & $\begin{array}{l}\text { This procedure, site procedures } \\
\text { and implementation plans }\end{array}$ & Complete & $\begin{array}{l}\text { Develop and issue Orders that implement Departmental Orders, } \\
\text { policies, procedures, requirements, and guidelines for the site's } \\
\text { records management program }\end{array}$ \\
\hline 1324.5A, Para 8b (2) & $\begin{array}{l}\text { This procedure; records } \\
\text { management implementation } \\
\text { plans are required for } \\
\text { sites/major organizations }\end{array}$ & Complete & $\begin{array}{l}\text { Implement and administer a records management control process to } \\
\text { ensure that records management program requirements are properly } \\
\text { identified. }\end{array}$ \\
\hline 1324.5A, Para 8b (3) & $\begin{array}{l}\text { Appendix B-4; Also, annual } \\
\text { Energy Systems Records } \\
\text { Management Plan to DOE- } \\
\text { ORO }\end{array}$ & Complete & $\begin{array}{l}\text { Formulate, continually update, and review at least annually a } \\
\text { records management plan which will allow the appropriate approving } \\
\text { (i.e., site management) or reviewing authorities (e.g., a DOE Field } \\
\text { Office) to judge the comprehensiveness and effectiveness of the } \\
\text { records management program. }\end{array}$ \\
\hline 1324.5A, Para 8b (4) & $\begin{array}{l}\text { Appendix B-4; Also, 1324.5A } \\
\text { Implementation Plan }\end{array}$ & Complete & $\begin{array}{l}\text { Ensure that plans are developed and implemented for conducting } \\
\text { continuous records management awareness and training to assure } \\
\text { that DOE and contractor personnel involved in managing, designing, } \\
\text { developing, using, and maintaining records systems are kept aware } \\
\text { of new requirements, and are trained in techniques to implement } \\
\text { them. }\end{array}$ \\
\hline 1324.5A, Para 8b (5) & $\begin{array}{l}\text { C-10, 11, } 15 \\
\text { Appendix B-3 }\end{array}$ & Complete & $\begin{array}{l}\text { Ensure that all records, especially those having lengthy retention } \\
\text { requirements, are provided protection in accordance with } \\
\text { requirements to preserve them free of environmental agents or } \\
\text { accidents that may cause deterioration or loss. }\end{array}$ \\
\hline
\end{tabular}


Table 2 (continued)

\begin{tabular}{|c|c|c|c|}
\hline \multicolumn{3}{|c|}{ Administrative and technical basis } & \multirow{2}{*}{$\begin{array}{l}\text { Lewel I docamear nember 10-101, Reconds Management, Rev. } 2 \\
\text { Requirement unit text/comments }\end{array}$} \\
\hline Compliance document & $\begin{array}{l}\text { Level } 1 \\
\text { document section }\end{array}$ & Flowdown status & \\
\hline 1324.5A, Para $8 b(6)$ & Appendix B-3 & Complete & $\begin{array}{l}\text { Ensure that records are not stored in DOE records storage facilities } \\
\text { for more than } 20 \text { years without National Archives and Records } \\
\text { Administration (NARA) approval. }\end{array}$ \\
\hline 1324.5A, Para 8b (7) & D-1, Appendix B-3 & Complete & $\begin{array}{l}\text { Ensure that site-specific records retention and disposition schedules } \\
\text { are developed, approved, and implemented. }\end{array}$ \\
\hline 1324.5A, Para 8b (8) & Appendix B-3 & $\begin{array}{l}\text { Complete; using } \\
\text { graded approach }\end{array}$ & $\begin{array}{l}\text { Ensure that records storage facilities meet the requirements of } \\
\text { NARA as provided in } 36 \text { CFR } 1228.222 \text {. }\end{array}$ \\
\hline 1324.5A, Para 8b (9) & C-10, Appendix B-2 & Complete & $\begin{array}{l}\text { Develop and implement a process for institutionalizing a disaster } \\
\text { recovery plan to ensure protection and preservation of records in } \\
\text { the event of a disaster. The plan should be based on an appropriate } \\
\text { risk assessment process commensurate with the risk of loss and } \\
\text { value of the records. }\end{array}$ \\
\hline '1324.5A, Para 8c (1) & Whole procedure & Complete & $\begin{array}{l}\text { A records management control process must ensure that the } \\
\text { following, as a minimum, are carried out: } \\
\text { Regulations implementing Departmental policies, procedures, and } \\
\text { guidelines for the records management program are developed and } \\
\text { issued. }\end{array}$ \\
\hline 1324.5A, Para 8c (2) & Appendix B-4 & Complete & $\begin{array}{l}\text { Self-assessments are conducted to determine whether or not the } \\
\text { records management program is managed effectively and efficiently. }\end{array}$ \\
\hline $1324.5 \mathrm{~A}$, para $8 \mathrm{c}(3)$ & Appendix B-4 & Complete & $\begin{array}{l}\text { Personnel who participate in managing, designing, developing, } \\
\text { operating, or maintaining records systems are trained to a level } \\
\text { commensurate with the records management activity performed. } \\
\text { Ensuring that employees know that official records may not be } \\
\text { removed without authorization is a singularly important training } \\
\text { objective. }\end{array}$ \\
\hline
\end{tabular}


Table 2 (continued)

\begin{tabular}{|c|c|c|c|}
\hline \multicolumn{3}{|c|}{ Administrative and technical basis } & \multirow[t]{2}{*}{ Level I doammeax member IO-101, Records Management, Rev. 2} \\
\hline Compliance document & $\begin{array}{c}\text { Level } 1 \\
\text { document section }\end{array}$ & Flowdown status & \\
\hline 1324.5A, Para 8c (4) & Appendix B-4 & Complete & $\begin{array}{l}\text { Follow-up procedures are in place to ensure implementation of } \\
\text { recommendations from compliance reviews or that the reasons for } \\
\text { not implementing such recommendations are documented. }\end{array}$ \\
\hline 1324.5A, Para 8c (5) & $\begin{array}{l}\text { Appendix B-4 } \\
\text { Implementation Plan for } \\
\text { 1324.5A }\end{array}$ & Complete & $\begin{array}{l}\text { Records management plans are approved by appropriate } \\
\text { management officials. (see } 8 \mathrm{~d} \text { for description of plan elements) }\end{array}$ \\
\hline 1324.5A, para 8d (1) & $\begin{array}{l}\text { Appendix B-4; } \\
\text { Direction to site/major } \\
\text { organization records managers }\end{array}$ & Complete & $\begin{array}{l}\text { A records management plan should reflect known program } \\
\text { deficiencies; and also work efforts, actions, or projects for correcting } \\
\text { those deficiencies in accordance with priorities and available staff. } \\
\text { Elements that are relative to the coverage of the plan and to the } \\
\text { environment of the site should be included, as follows: } \\
\text { (1) Summary of the management control process describing the } \\
\text { records management program of the site. If special provisions apply } \\
\text { to selected records management initiatives or records holdings, this } \\
\text { information should be included. }\end{array}$ \\
\hline 1324.5A, Para 8d (2) & $\begin{array}{l}\text { Appendix B-4 } \\
\text { Direction to site/major } \\
\text { organization records managers }\end{array}$ & Complete & $\begin{array}{l}\text { References to lists that uniquely identify assistant RMSs and the } \\
\text { recordkeepers and their official file stations. }\end{array}$ \\
\hline 1324.5A, Para 8d (3) & $\begin{array}{l}\text { Appendix B-4 } \\
\text { Direction to site/major } \\
\text { organization records managers }\end{array}$ & Complete & $\begin{array}{l}\text { Reference to schedules indicating any type of self-assessments. } \\
\text { Schedules should, at a minimum, indicate the fiscal year planned for } \\
\text { such tasks. }\end{array}$ \\
\hline 1324.5A, Para 8d (4) & $\begin{array}{l}\text { Appendix B-4 } \\
\text { Directive to site/major } \\
\text { organization records managers }\end{array}$ & Complete & $\begin{array}{l}\text { Reference to documents containing the results of the latest } \\
\text { compliance review and follow-up actions on previous } \\
\text { recommendations from the review. }\end{array}$ \\
\hline
\end{tabular}


Table 2 (continued)

\begin{tabular}{|c|c|c|c|}
\hline \multicolumn{3}{|c|}{ Administrative and technical basis } & \multirow[t]{2}{*}{ Level 1 docanent mmber IO-101, Reconds Management, Rev. 2} \\
\hline Compliance document & $\begin{array}{c}\text { Level } 1 \\
\text { document section }\end{array}$ & Flowdown status & \\
\hline 1324.5A, Para 8d (5) & $\begin{array}{l}\text { Appendix B-4 } \\
\text { Direction to site/major } \\
\text { organization records managers }\end{array}$ & Complete & $\begin{array}{l}\text { Reference to a plan for continually providing records management } \\
\text { program awareness and training to personnel who manage, design, } \\
\text { develop, operate, maintain, or use records management. Plans for } \\
\text { on-site personnel should include, as a minimum, training schedule, } \\
\text { type of training, personnel attending, and date of attendance. }\end{array}$ \\
\hline 1324.5A, Para 8d (6) & $\begin{array}{l}\text { Appendixes B-4, C-3 } \\
\text { Direction to site/major } \\
\text { organization records managers }\end{array}$ & Complete & $\begin{array}{l}\text { Reference to lists which identify emergency response personnel and } \\
\text { locations where they may be contacted. }\end{array}$ \\
\hline $\begin{array}{l}\text { OR } 1324.5,4 / 88, \text { Records } \\
\text { Management Program }\end{array}$ & N/A & $\mathbf{N} / \mathbf{A}$ & $\begin{array}{l}\text { General:This order assigns OR responsibilities for implementing } \\
\text { DOE 1324.5. }\end{array}$ \\
\hline $\begin{array}{l}\text { DOE Order } 1324.6,7 / 8 / 87 \\
\text { Automated Office Electronic } \\
\text { Recordkeeping } \\
\text { 7a, } \\
\text { Legal Requirements }\end{array}$ & $\begin{array}{l}\text { B-1,2; A-1,2,3; } \\
\text { Appendix C-5 }\end{array}$ & $\begin{array}{l}\text { Complete } \\
\text { NOTE: Requirements } \\
\text { for Electronic } \\
\text { Records in procedure } \\
\text { text were taken from } \\
\text { 36CFR, Chap. } \\
\text { XII.1234, which is } \\
\text { more current }\end{array}$ & $\begin{array}{l}\text { Agency heads are required to make and preserve records containing } \\
\text { adequate and proper documentation of the organization, functions, } \\
\text { policies, decisions, procedures, and essential transactions of the } \\
\text { agency and designed to furnish the information necessary to protect } \\
\text { the legal and financial rights of the Gov. and of persons directly } \\
\text { affected by the agency's activities. }\end{array}$ \\
\hline 1324.6, Para 8 & Appendix C-5; & Complete & $\begin{array}{l}\text { Records officers and all other personnel relying on electronic } \\
\text { recordkeeping shall provide for cost effective, adequate, and proper } \\
\text { documentation of Departmental functions, activities, and operations; } \\
\text { access and usage controls to prevent unauthorized access to loss of, } \\
\text { removal of, or theft of Departmental records created or acquired in } \\
\text { electronic form; and that all records in electronic form have } \\
\text { authorized disposition in accordance with } 1324.2 \text {. }\end{array}$ \\
\hline
\end{tabular}


Table 2 (continued)

\begin{tabular}{|c|c|c|c|}
\hline \multicolumn{3}{|c|}{ Administrative and technical basis } & \multirow{2}{*}{$\begin{array}{l}\text { Level } 1 \text { deamen number IO-101, Reconds Management, Rev. } 2 \\
\text { Requirement unit text/comments }\end{array}$} \\
\hline Compliance document & $\begin{array}{c}\text { Level } 1 \\
\text { document section }\end{array}$ & Flowdown status & \\
\hline 1324.6, Para 9b & Appendix C-5 & Complete & $\begin{array}{l}\text { Personnel shall provide accurate and specific external labels for disks } \\
\text { and diskettes. External labels shall include: title, dates, software, and } \\
\text { file code and identification of the equipment on which the records } \\
\text { were created. }\end{array}$ \\
\hline 1324.6, Para 9c & Appendix C-5 & Complete & $\begin{array}{l}\text { Personnel shall use readily understandable and standard internal } \\
\text { document labels so that they, their colleagues, and their successors } \\
\text { can retrieve electronically stored information. }\end{array}$ \\
\hline 1324.6, Para 10a & Appendix C-5 & Compiete & $\begin{array}{l}\text { Subject filed electronic records shall be coded in accordance with } \\
\text { DOE } 0000.1 \mathrm{~A} \text { or its contractor equivalent. Every flexible disk shall } \\
\text { be labeled. Every document shall be coded, named, dated, and } \\
\text { described accurately and in sufficient detail to permit its retrieval. }\end{array}$ \\
\hline 1324.6, Para $10 \mathrm{~b}$ & Appendix C-5 & Complete & $\begin{array}{l}\text { Case filed electronic records shall be indexed. (1) Include such } \\
\text { things as date, subject, sender, receiver, and number (case contract, } \\
\text { purchase order, and so forth). (2) Diskette indexes should be } \\
\text { printed out to ensure easy access. }\end{array}$ \\
\hline 1324.6, Para $11 b$ & $\begin{array}{l}\text { Appendix C-5 } \\
\text { Appendix B-3 }\end{array}$ & Compiete & $\begin{array}{l}\text { Retrieving Electronically Stored Records. Permanent records that } \\
\text { are to be transferred to NARA and are stored on disks or diskettes } \\
\text { shall be converted either to magnetic tape ( } 36 \text { CFR } 1228.188 \\
\text { formerly Federal Property Management Regulation (FPMR) } \\
\text { subpart 101-11.411-6) or converted to paper or microform. } \\
\text { (Microforms should meet the standards in } 36 \text { CFR part } 1230 \text {, } \\
\text { formerly FPMR subpart 101-11.5) Submit through channels, DOE } \\
\text { F 1324.5, Records Retention and Disposal Authorization, to obtain } \\
\text { disposition authorization. }\end{array}$ \\
\hline
\end{tabular}


Table 2 (continued)

\begin{tabular}{|c|c|c|c|}
\hline \multicolumn{3}{|c|}{ Administrative and technical basis } & \multirow[t]{2}{*}{ 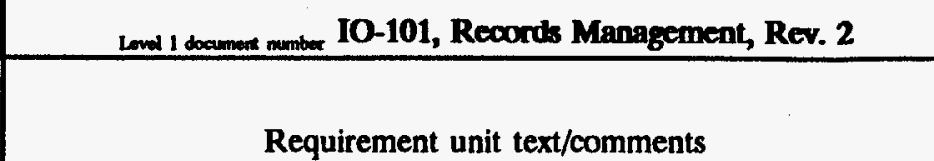 } \\
\hline Compliance document & $\begin{array}{c}\text { Level } 1 \\
\text { document section }\end{array}$ & Flowdown status & \\
\hline 1324.6, Para 12d & Appendix C-5 & Complete & $\begin{array}{l}\text { Ensuring the Retention of Records. Since many electronic mail } \\
\text { systems automatically erase information after the recipient has read } \\
\text { it, personnel shall take positive action at the time they receive } \\
\text { electronic messages to retain any record received in this manner and } \\
\text { transfer it to a medium which will satisfactorily store the record until } \\
\text { its disposition date. }\end{array}$ \\
\hline 1324.6, Para $12 e$ & B-3; Appendix C-5 & Complete & $\begin{array}{l}\text { If the Same information is contained on more than one medium } \\
\text { (such as paper and disk), the disposition of the records on both } \\
\text { media shall be scheduled. }\end{array}$ \\
\hline 1324.6, Para 13a & $\begin{array}{l}\text { Appendix C-5 } \\
\text { Appendix B-3 }\end{array}$ & Complete & $\begin{array}{l}\text { Electronic records can only be destroyed according to an } \\
\text { authorization. Authorized records retention standards and } \\
\text { procedures for obtaining approval of new standards for records not } \\
\text { presently covered are contained in DOE } 1324.2 \text {. }\end{array}$ \\
\hline 1324.6, Para 13b & N/A & $\begin{array}{l}\text { N/A. DOE Orders } \\
1360.2,5636.2 \text {, and } \\
5636.4 \text { are cancelled } \\
\text { and out of date. } \\
\text { Assessment } \\
\text { completed by Ron } \\
\text { Marcum, Computer } \\
\text { Security }\end{array}$ & $\begin{array}{l}\text { Requirements for transmitting, storing, disposing, and protecting } \\
\text { security classified or sensitive unclassified records are contained in } \\
\text { DOE } 1360.2,5632.4,5635.1,5636.2 \text {, and } 5636.4 \text {. }\end{array}$ \\
\hline
\end{tabular}




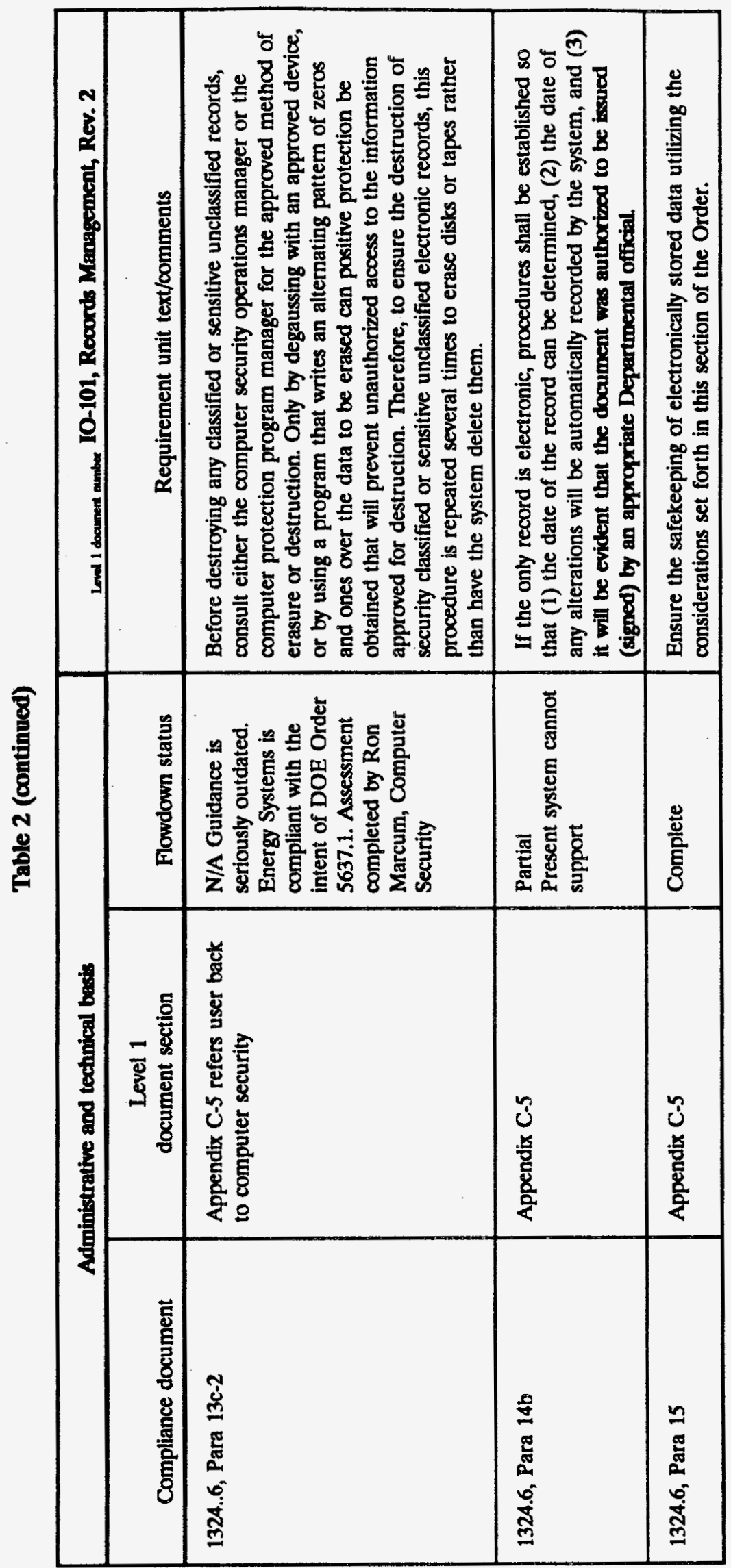


Table 2 (continued)

\begin{tabular}{|c|c|c|c|}
\hline \multicolumn{3}{|c|}{ Administrative and technical basis } & \multirow{2}{*}{$\begin{array}{l}\text { Leve } 1 \text { doomeat number IO-101, Reconds Management, Rev. } 2 \\
\text { Requirement unit text/comments }\end{array}$} \\
\hline Compliance document & $\begin{array}{l}\text { Level } 1 \\
\text { document section }\end{array}$ & Flowdown status & \\
\hline 1324.6, Para $15 e$ & N/A & $\begin{array}{l}\text { N/A This section is } \\
\text { derived from an out } \\
\text { of date order. Energy } \\
\text { Systems is in } \\
\text { compliance with the } \\
\text { replacement order. } \\
\text { Assessment } \\
\text { completed by Ron } \\
\text { Marcum, Computer } \\
\text { Security. }\end{array}$ & $\begin{array}{l}\text { Unclassified, sensitive electronic records shall not be processed } \\
\text { without the express written approval of the Computer Protection } \\
\text { Program Manager in accordance with DOE } 1360.2 \text { Consult him or } \\
\text { her for any specific requirements for processing unclassified data or } \\
\text { applications, e.g., color coded or specially marked diskettes. In } \\
\text { addition, the Computer Protection Program Manager must certify } \\
\text { "that new or significantly changed sensitive computer applications } \\
\text { are design reviewed and system tested prior to operational } \\
\text { use...Upon successful completion of the system test, the Computer } \\
\text { Protection Program Manager shall certify that the system meets the } \\
\text { documented and approved system protection specification: related } \\
\text { applicable Federal policies, regulations, and standards; and that the } \\
\text { results of the test demonstrate that the protection provisions are } \\
\text { adequate to safeguard the sensitive data processed." }\end{array}$ \\
\hline 1324.6, Para 16 & Appendix C-5 & Complete & $\begin{array}{l}\text { Software for Electronic Systems. (c) The system must be able to } \\
\text { accommodate the data transportability specifications for those } \\
\text { permanent records that will be transferred to NARA (see } 36 \text { CFR } \\
1228.188 \text { ); (d) When planning a new system or revising an existing } \\
\text { system, managers shall plan for the disposition of the electronic } \\
\text { records in the system. }\end{array}$ \\
\hline $\begin{array}{l}\text { DOE Order 1324.7A, 3/26/92, } \\
\text { Departmental History Program } \\
\text { 8c Responsibilities }\end{array}$ & $\begin{array}{l}\text { B; } \\
\text { D-1 } \\
\text { Appendix B-3 }\end{array}$ & Complete & $\begin{array}{l}\text { Summary: Assure that file custodians develop and maintain systems } \\
\text { which facilitate the identification and preservation of records of } \\
\text { historical value; Identify these records on DOE F } 1324.10 \text { and } \\
\text { forward to DOE Chief Historian for review and further disposition } \\
\text { instructions. Retire these files according to provisions in } 1324.2 \mathrm{~A} \\
\text { and HO } 1324.1 \mathrm{~A} \text {. Consult with Departmental Records Officer, as } \\
\text { necessary, in distinguishing official records from personal papers; } \\
\text { coordinate with Chief Historian to determine historical value of } \\
\text { records; coordinate all history and archival projects with Chief } \\
\text { Historian for authorization and approval. }\end{array}$ \\
\hline
\end{tabular}


Table 2 (continued)

\begin{tabular}{|c|c|c|c|}
\hline \multicolumn{3}{|c|}{ Administrative and technical basis } & \multirow[t]{2}{*}{ Level I daamear mmbax 10-101, Reconds Management, Rev. 2} \\
\hline Compliance document & $\begin{array}{c}\text { Level } 1 \\
\text { document section }\end{array}$ & Flowdown status & \\
\hline $\begin{array}{l}\text { DOE Order } 1324.8,10 / 23 / 91, \\
\text { Rights and Interests Records } \\
\text { Protection Program } \\
\text { Para } 9\end{array}$ & A, B; Appendix C-4 & $\begin{array}{l}\text { Complete; graded } \\
\text { approach }\end{array}$ & $\begin{array}{l}\text { Because it is impossible to ensure the availability of every important } \\
\text { document, sound judgment shall be used in identifying these } \\
\text { records. }\end{array}$ \\
\hline 1324.8, Para 10a & C-15; Appendixes B-3, C-4 & Complete & $\begin{array}{l}\text { Storage locations used shall provide adequate protection and } \\
\text { accessibility and shall meet the risk level of fire protection required } \\
\text { by DOE directives. }\end{array}$ \\
\hline 1324.8, Para $10 \mathrm{~b}$ & C-9-15; Appendixes B-3; C-4 & Complete & $\begin{array}{l}\text { Records will be stored at the site in such a manner as to assure ease } \\
\text { of access and retrieval. The site sill have the necessary capability to } \\
\text { make the records immediately useful. }\end{array}$ \\
\hline $\begin{array}{l}\text { DOE Order } 5480.8 \mathrm{~A}, 6 / 26,92 \\
\text { (Change 1: 10/19/92), } \\
\text { Contractor Occupational } \\
\text { Medical Program } \\
11 \text { e (3) }\end{array}$ & Appendix C-1 & Complete & $\begin{array}{l}\text { Access to Employee Medical Records. Access to employee medical } \\
\text { records shall be in accordance with: a) the Privacy Act as codified in } \\
10 \text { CFR 1008.17(b)(1); and b) "Access to Exposure and Medical } \\
\text { Records" as codified in } 29 \text { CFR 1910.20 (OSHA Standard). }\end{array}$ \\
\hline $\begin{array}{l}5480.8 A \\
11 \text { e 6) }\end{array}$ & D; Appendixes C-1 & Complete & $\begin{array}{l}\text { Retention of Medical Records. All employee health records shall be } \\
\text { retained in accordance with DOE 1324.2A. However, inactive } \\
\text { records may be retired to low-cost storage in an on-site records } \\
\text { holding area or a Federal Records Center (FRC). To protect the } \\
\text { confidentiality of the records, the shipping cartons shall be sealed } \\
\text { and the transfer documents shall note that access to the records is } \\
\text { limited to personnel of the Contractor Medical Department. If } \\
\text { resources are available, the files may be microfilmed and the paper } \\
\text { records destroyed. }\end{array}$ \\
\hline $\begin{array}{l}\text { DOE Order 5500.7B, 10/23/91, } \\
\text { Emergency Operating Records } \\
\text { Protection Program } \\
\text { Para } 10[1]\end{array}$ & B; Appendix C-3 & $\begin{array}{l}\text { Complete; graded } \\
\text { approach }\end{array}$ & $\begin{array}{l}\text { Because it is impossible to ensure the availability of every important } \\
\text { document, sound judgment shall be used in identifying emergency } \\
\text { operating records. }\end{array}$ \\
\hline
\end{tabular}


Table 2 (continued)

\begin{tabular}{|c|c|c|c|}
\hline \multicolumn{3}{|c|}{ Administrative and technical basis } & \multirow{2}{*}{$\begin{array}{l}\text { Lenel I doument mumber IO-101, Records Management, Rev. } 2 \\
\text { Requirement unit text/comments }\end{array}$} \\
\hline Compliance document & $\begin{array}{c}\text { Level } 1 \\
\text { document section }\end{array}$ & Flowdown status & \\
\hline $5500.7 \mathrm{~B}$, Para $10[3]$ & Appendix C-3 & Complete & Official record copies shall not be used. \\
\hline 5500.7B, Para 11a & Appendix C-3 & Complete & $\begin{array}{l}\text { Emergency Operating Centers (EOCs) and relocation sites, as } \\
\text { developed, shall provide adequate protection and accessibility, and } \\
\text { shall meet the improved rist kevel of fire protection required by } \\
\text { DOE } 5480.7 \text {. Storage of classified documents at these sites shall be } \\
\text { approved in accordance with DOE 5634.1A prior to use. }\end{array}$ \\
\hline 5500.7B, Para 11b & Appendix C-3 & Complete & $\begin{array}{l}\text { Records will be stored at the site in such a manner as to ensure } \\
\text { ease of access, retrieval, and control. The site will have the necessary } \\
\text { capability to make the records immediately available. Classified } \\
\text { records shall be handled in accordance with DOE } 5632.5 \text { and DOE } \\
5635.1 \text {. UCNI reconds will be controlled in acoordanoe with DOE } \\
\text { 5635.4. }\end{array}$ \\
\hline 5500.7B, Para 11c & Appendix C-3 & Complete & $\begin{array}{l}\text { Emergency Operating records shall be maintained until they are } \\
\text { superseded or replaced. Once superseded, these records revert to } \\
\text { standard records disposition requirements. }\end{array}$ \\
\hline $\begin{array}{l}\text { DOE Order } 5700.6 C, 8 / 21 / 91, \\
\text { Quality Assurance } \\
\text { Para 9b (1), Criterion } 4\end{array}$ & $\begin{array}{l}\text { A, B, C, D } \\
\text { Appendix B }\end{array}$ & Complete & $\begin{array}{l}\text { Records shall be specified, prepared, reviewed, approved, and } \\
\text { maintained. }\end{array}$ \\
\hline $\begin{array}{l}\text { DOE Order } 5700.6 \mathrm{C}, 8 / 21 / 91 \text {, } \\
\text { Attachment I, } 4 \text { b (1) }\end{array}$ & $\begin{array}{l}\text { A, B, C, D, E } \\
\text { Appendixes B,C }\end{array}$ & Complete & $\begin{array}{l}\text { A process should be established and implemented to ensure that } \\
\text { sufficient records (for example, records of design, environmental } \\
\text { conditions, applied research and development, procurement, } \\
\text { construction, data acquisition, assessments, inspection, testing, } \\
\text { maintenance, and modification) are specified, prepared, reviewed, } \\
\text { approved, and maintained to accurately reflect completed work. The } \\
\text { maintenance of records should include provisions for retention, } \\
\text { protection, preservation, traceability, accountability, and } \\
\text { retrievability. }\end{array}$ \\
\hline
\end{tabular}


Table 2 (continued)

\begin{tabular}{|c|c|c|c|}
\hline \multicolumn{3}{|c|}{ Administrative and technical basis } & \multirow[t]{2}{*}{ Level 1 docamert number IO-101, Records Management, Rev. 2} \\
\hline Compliance document & $\begin{array}{c}\text { Level } 1 \\
\text { document section }\end{array}$ & Flowdown status & \\
\hline $\begin{array}{l}\text { DOE Order } 5700.6 \mathrm{C}, 8 / 21 / 91 \text {, } \\
\text { Attachment } \mathrm{I}, 4 \mathrm{~b}(2)\end{array}$ & Appendix C-5,6,7,8,9 & Complete & $\begin{array}{l}\text { For records that require special processing and control, such as } \\
\text { computer codes or information on high density media or optical } \\
\text { disks, hardware and software required to maintain and access } \\
\text { records should be controlled to ensure records are usable. }\end{array}$ \\
\hline $\begin{array}{l}\text { DOE Order } 5700.6 \mathrm{C}, 8 / 21 / 91 \text {, } \\
\text { Attachment I, } 4 \text { b (3) }\end{array}$ & C-9,14,15; D-1; Appendix B-3 & Complete & $\begin{array}{l}\text { Records holding facilities are reserved for storage of inactive records } \\
\text { and may not meet the physical requirements or have appropriate } \\
\text { staff to maintain active records. Active records requiring special } \\
\text { handling, storage, and processing should not be sent to records } \\
\text { holding facilities. Users should refer to the General Records } \\
\text { Schedule (GRS) or DOE 1324.2A for retention and disposition of } \\
\text { records. }\end{array}$ \\
\hline $\begin{array}{l}\text { DOE Order } 5700.6 \mathrm{C}, 8 / 21 / 91 \text {, } \\
\text { Attachment } \mathrm{I}, 4 \mathrm{~b}(4-5)\end{array}$ & Appendix B-3 (H-L) & Complete & $\begin{array}{l}\text { (4) NARA exercises final authority for approving the disposition of } \\
\text { Govt. records. Use of the GRS and DOE Records Schedule } \\
\text { (DOERS) is mandatory. } \\
\text { (5)...Care should be taken to follow requirements of both NARA } \\
\text { and standards offering interpretive QA guidance but using different } \\
\text { terminology. }\end{array}$ \\
\hline $\begin{array}{l}\text { ASME NQA-1, Basic } \\
\text { Requirements, 1989, } \\
\text { 17, Quality Assurance Records }\end{array}$ & $\begin{array}{l}\text { A; B; } \\
\text { D;C; Appendix B }\end{array}$ & Complete & $\begin{array}{l}\text { Records that furnish documentary evidence of quality shall be } \\
\text { specified, prepared, and maintained. Records shall be legible, } \\
\text { identifiable, and retrievable; protected against damage, deterioration, } \\
\text { or loss. Requirements and responsibilities for record transmittal, } \\
\text { distribution, retention, maintenance, disposition shall be established } \\
\text { and documented. }\end{array}$ \\
\hline $\begin{array}{l}\text { ASME NQA-1-1989, } \\
\text { Supplement 17S-1 } \\
2.1 \text {, Records System }\end{array}$ & $\begin{array}{l}\text { A, B, C, D; } \\
\text { Appendix B }\end{array}$ & Complete & $\begin{array}{l}\text { A records system(s) shall be established by the organization } \\
\text { responsible at the earliest practicable time consistent with the } \\
\text { schedule for accomplishing work activities and in compliance with } \\
\text { the general requirements of this Supplement. The records system(s) } \\
\text { shall be defined, implemented, and enforced in accordance with } \\
\text { written procedures, instructions, or other documentation. }\end{array}$ \\
\hline
\end{tabular}


Table 2 (continued)

\begin{tabular}{|c|c|c|c|}
\hline \multicolumn{3}{|c|}{ Administrative and tectinical basis } & \multirow{2}{*}{ 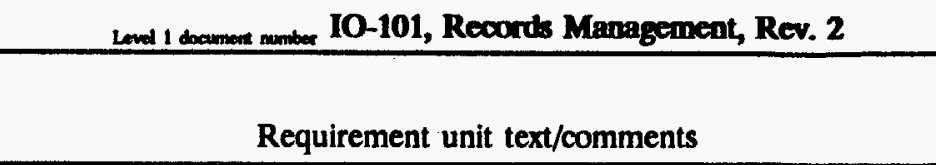 } \\
\hline Compliance document & $\begin{array}{c}\text { Level } 1 \\
\text { document section }\end{array}$ & Flowdown status & \\
\hline $\begin{array}{l}\text { NQA-1, 17S-1 } \\
2.2 \text { Generation of Records }\end{array}$ & $\begin{array}{l}\text { A; B; C, D } \\
\text { Appendix B }\end{array}$ & Complete & $\begin{array}{l}\text { The applicable design specifications, procurement documents, test } \\
\text { procedures, operational procedures, or other documents shall specify } \\
\text { the records to be generated, supplied, or maintained by or for the } \\
\text { Owner. Documents that are designated to become records shall be } \\
\text { legible, accurate, and completed appropriate to the work } \\
\text { accomplished. }\end{array}$ \\
\hline $\begin{array}{l}\text { NQA-1, 17S-1 } \\
2.3 \text { Record Validation }\end{array}$ & C-2; Appendix D & Complete & $\begin{array}{l}\text { Documents shall be considered valid records only if stamped, } \\
\text { initialed, or signed and dated by authorized personnel or otherwise } \\
\text { authenticated. This authentication may take the form of a statement } \\
\text { by the responsible individual or organization. Handwritten signatures } \\
\text { are not required if the document is clearly identified as a statement } \\
\text { by the reporting individual or organization. These records may be } \\
\text { originals or reproduced copies. }\end{array}$ \\
\hline $\begin{array}{l}\text { NOA-1, 17S-1 } \\
2.4 \text { Index }\end{array}$ & C-3; Appendix B-2,3 & Complete & $\begin{array}{l}\text { The records shall be indexed. The indexing system(s) shall include, } \\
\text { as a minimum, record retention times and the location of the record } \\
\text { within the record system. }\end{array}$ \\
\hline $\begin{array}{l}\text { NQA-1, } 175-1 \\
2.5 \text { Distribution } \\
\end{array}$ & Procedure & Complete & $\begin{array}{l}\text { The records shall be distributed, handled, and controlled in } \\
\text { accordance with written procedures. }\end{array}$ \\
\hline $\begin{array}{l}\text { NQA-1, 17S-1 } \\
2.6 \text { Identification }\end{array}$ & C-3; Appendix B-2 & Complete & $\begin{array}{l}\text { Records and/or indexing system(s) shall provide sufficient } \\
\text { information to permit identification between the record and the } \\
\text { item(s) or activities to which it applies. }\end{array}$ \\
\hline $\begin{array}{l}\text { NQA-1, 17S-1 } \\
2.7 \text { Classification }\end{array}$ & $\begin{array}{l}\text { B-5; Appendixes B-1, } \\
\text { D }\end{array}$ & Complete & $\begin{array}{l}\text { Records shall be classified as Lifetime or Nonpermanent by the } \\
\text { Owner, or his agent when authorized in accordance with the criteria } \\
\text { given in paras. } 2.7 .1 \text { and } 2.7 .2 \text { below. }\end{array}$ \\
\hline
\end{tabular}


Table 2 (continued)

\begin{tabular}{|c|c|c|c|}
\hline \multicolumn{3}{|c|}{ Administrative and tochnical basis } & \multirow[t]{2}{*}{ Lovel 1 doament member 10-101, Records Management, Rev. 2} \\
\hline Compliance document & $\begin{array}{c}\text { Level } 1 \\
\text { document section }\end{array}$ & Flowdown status & \\
\hline $\begin{array}{l}\text { NQA-1, 17S-1 } \\
\text { 2.7.1 Lifetime Records }\end{array}$ & B-5; Appendixes B-1, D & Complete & $\begin{array}{l}\text { Lifetime records are those that meet one or more of the following } \\
\text { criteria: (a) would be of significant value in demonstrating capability } \\
\text { for safe operation; (b) would be of significant value in maintaining, } \\
\text { reworking, repairing, replacing or modifying an item; (c) would be of } \\
\text { significant value in determining the cause of an accident or } \\
\text { malfunction of an item; (d) would provide required baseline data for } \\
\text { in-service inspections. Lifetime records are required to be } \\
\text { maintained by or for the plant owner for the life of the particular } \\
\text { item while it is installed in the plant or stored for future use. }\end{array}$ \\
\hline $\begin{array}{l}\text { NQA-1, 17S-1 } \\
\text { 2.7.2 Nonpermaneni Records }\end{array}$ & B-5; Appendixes B-1, D & Complete & $\begin{array}{l}\text { Nonpermanent records are those required to show evidence that an } \\
\text { activity was performed in accordance with the applicable } \\
\text { requirements but need not be retained for the life of the item } \\
\text { because they do not meet the criteria for lifetime records. }\end{array}$ \\
\hline $\begin{array}{l}\text { NQA-1, 17S-1 } \\
2.8 \text { Retention of Records }\end{array}$ & D-1; Appendix B-3 & Complete & $\begin{array}{l}\text { Records shall be retained in accordance with the above } \\
\text { classifications. The retention period for nonpermanent records shall } \\
\text { be established in writing. }\end{array}$ \\
\hline $\begin{array}{l}\text { NQA-1, 17S-1 } \\
2.9 \text { Corrected Information in } \\
\text { Records }\end{array}$ & C-1; Appendix B-2 & Complete & $\begin{array}{l}\text { Records may be corrected in accordance with procedures which } \\
\text { provide for appropriate review or approval by the originating } \\
\text { organization. The correction shall include the date and the } \\
\text { identification of the person authorized to issue such correction. }\end{array}$ \\
\hline $\begin{array}{l}\text { NQA-1, 17S-1 } \\
\text { 3.1 Receipt Responsibility }\end{array}$ & C-12 & Complete & $\begin{array}{l}\text { The individual or organization responsible for receiving records shall } \\
\text { provide protection from damage or loss during the time that the } \\
\text { records are in their possession. }\end{array}$ \\
\hline
\end{tabular}


Table 2 (continued)

\begin{tabular}{|c|c|c|c|}
\hline \multicolumn{3}{|c|}{ Administrative and technical basis } & \multirow[t]{2}{*}{ Loval 1 docameax mumber IO-101, Reconds Management, Rev. 2} \\
\hline Compliance document & $\begin{array}{c}\text { Level } 1 \\
\text { document section }\end{array}$ & Flowdown status & \\
\hline $\begin{array}{l}\text { NQA-1, 17S-1 } \\
\text { 3.2 Receipt Control }\end{array}$ & C-12, 13,14; Appendix B-2,3 & Complete & $\begin{array}{l}\text { Each organization responsible for the receipt of records shall } \\
\text { designate a person or organization responsible for receiving the } \\
\text { records. The designee shall be responsible for organizing and } \\
\text { implementing a system of receipt control of records for permanent } \\
\text { and temporary storage. } \\
\text { As a minimum, a receipt control system shall include the following: } \\
\text { (a) a method for designating the required records; (b) a method for } \\
\text { identifying records received; (c) procedure for receipt and inspection } \\
\text { of incoming records; (d) a method for submittal of completed } \\
\text { records to the storage facility without unnecessary delay. }\end{array}$ \\
\hline $\begin{array}{l}\text { NQA-1, 17S-1 } \\
\text { 3.3 Status }\end{array}$ & C-12 & Complete & $\begin{array}{l}\text { Each receipt control system shall be structured to permit a current } \\
\text { and accurate assessment of the status of records during the } \\
\text { receiving process. }\end{array}$ \\
\hline $\begin{array}{l}\text { NQA-1, 17S-1 } \\
\text { 4.1 Storage }\end{array}$ & C; Appendixes B-2, 3 & Complete & $\begin{array}{l}\text { The records shall be stored in predetermined locations that meet the } \\
\text { requirements of applicable standards, codes, and regulatory agencies. } \\
\text { Prior to storage of records, a written storage procedure shall be } \\
\text { prepared and responsibility assigned for enforcing the requirements. } \\
\text { It shall include, as a minimum, a-g: } \\
\text { (a) description of storage facility; (b) filing system to be used; (c) } \\
\text { method for verifying records received agree with transmittal } \\
\text { document and are legible; (d) method for verifying records are those } \\
\text { designated (3.2); (e) rules governing access to and control of files; } \\
\text { (f) method for maintaining control of and accountability for records } \\
\text { removed from the storage facility; (g) method for filing } \\
\text { supplemental information (2.9) and disposing of superseded records. }\end{array}$ \\
\hline
\end{tabular}


Table 2 (continued)

\begin{tabular}{|c|c|c|c|}
\hline \multicolumn{2}{|c|}{ Administrative and tochnical besis } & . & \multirow[t]{2}{*}{ Level 1 doament number 10-101, Records Management, Rev. 2} \\
\hline Compliance document & $\begin{array}{c}\text { Level } 1 \\
\text { document section }\end{array}$ & Flowdown status & \\
\hline $\begin{array}{l}\text { NQA-1, 17S-1 } \\
4.2 \text { Preservation }\end{array}$ & $\begin{array}{l}\text { C- 9--15 } \\
\text { Appendixes B-2,3; C-5-9 }\end{array}$ & Complete & $\begin{array}{l}\text { Records shall be stored in a manner approved by the organization } \\
\text { or organizations responsible for storage. In order to preclude } \\
\text { deterioration of the records the requirements of a-c shall apply: (a) } \\
\text { Provisions shall be made in the storage arrangement to prevent } \\
\text { damage from moisture, temperature, and pressure. (b) Records } \\
\text { shall be firmly attached in binders or placed in folders or envelopes } \\
\text { for storage in steel file cabinets. (c) Provisions shall be made for } \\
\text { special process records (such as radiographs, photographs, negatives, } \\
\text { microform, and magnetic media) to prevent damage from excessive } \\
\text { light, stacking, electromagnetic fields, temperature, and humidity. }\end{array}$ \\
\hline $\begin{array}{l}\text { NQA-1, } 17 \text { S-1 } \\
4.3 \text { Safekeeping }\end{array}$ & C. 4-6, 13; Appendix B-3 & Complete & $\begin{array}{l}\text { Measures shall be established to preclude the entry of unauthorized } \\
\text { personnel into the storage area. These measures shall guard against } \\
\text { larceny and vandalism. Measures shall be taken to provide for } \\
\text { replacement, restoration, or substitution of lost or damaged records. }\end{array}$ \\
\hline $\begin{array}{l}\text { NQA-1, 17S-1 } \\
4.4 \text { Facility }\end{array}$ & Appendix B-3 & Complete & $\begin{array}{l}\text { Records shall be stored in facilities constructed and maintained in a } \\
\text { manner which minimizes the risk of damage or destruction from the } \\
\text { following: (a) natural disasters such as winds, floods, or fires; (b) } \\
\text { environmental conditions such as high and low temperatures and } \\
\text { humidity; (c) infestation of insects, mold, or rodents. There are two } \\
\text { satisfactory methods of providing storage facilities: single or dual. } \\
\text { See Sections } 4.4 .1-4.4 .4 \text { for details. }\end{array}$ \\
\hline $\begin{array}{l}\text { NQA-1, 17S-1 } \\
5 \text { Retrieval }\end{array}$ & Appendix B-3 & Partial & $\begin{array}{l}\text { Storage systems shall provide for retrieval of information in } \\
\text { accordance with planned retrieval times based upon the record type. } \\
\text { A list shall be maintained designating those personnel who shall } \\
\text { have access to the files. Reconds maintained by a Supplier at his } \\
\text { facility or other location shall be accessible to the Purchaser or his } \\
\text { designated alternate. }\end{array}$ \\
\hline
\end{tabular}


Table 2 (continued)

\begin{tabular}{|c|c|c|c|}
\hline \multicolumn{3}{|c|}{ Administrative and tochnical basis } & \multirow{2}{*}{$\begin{array}{l}\text { Lovel } 1 \text { docement mmber 10-101, Reconds Management, Rev. } 2 \\
\text { Requirement unit text/comments }\end{array}$} \\
\hline Compliance document & $\begin{array}{c}\text { Level } 1 \\
\text { document section }\end{array}$ & Flowdown status & \\
\hline $\begin{array}{l}\text { NQA-1, 17S-1 } \\
6 \text { Disposition }\end{array}$ & $\begin{array}{l}\text { A-3; C-9,12,14; } \\
\text { Appendix B-1,3 }\end{array}$ & Partial & $\begin{array}{l}\text { Records accumulated at various locations, prior to transfer shall be } \\
\text { made accessible to the Owner directly or through the procuring } \\
\text { organization. The custodian shall inventory the submittals, } \\
\text { acknowledge receipt, and process these records in accordance with } \\
\text { this Standard. Various regulatory agencies have requirements } \\
\text { concerning records that are within the scope of this Standard. The } \\
\text { most stringent requirements shall be used in determining the final } \\
\text { disposition. the Supplier's nonpermaneat reconds shall not be } \\
\text { disposed of until the applicable conditions bisted in a-e are satisfied: } \\
\text { (a) items are released for shipment, a Code Data Report is signed, } \\
\text { or a Code Symbol Stamp is affired; (b) regulatory requirements are } \\
\text { satisfied; (c) operational status permitts; (d) warranty consideration is } \\
\text { satisfied; (c) Purchaser's requirements are satisfied. }\end{array}$ \\
\hline $\begin{array}{l}\text { DOE Order } 1324.4,11 / 2 / 83 \text {, } \\
\text { Micrographics Management } \\
\text { Section 8a-b }\end{array}$ & Appendix C-6 & $\begin{array}{l}\text { Complete; } \\
\text { requirements for } \\
\text { Appendix C-6 came } \\
\text { from } 36 \text { CFR XII, } \\
1230\end{array}$ & $\begin{array}{l}\text { Summary: In accordance with FPMR Section 101-11.505, } \\
\text { Micrographics Systems Analysis, conduct a system analysis (including } \\
\text { cost/benefit) prior to decision to establish a new or significant } \\
\text { enhancement to a micrographic system. }\end{array}$ \\
\hline $1324.4,9 a$ & Appendix C-6 & Complete & $\begin{array}{l}\text { Microfilm copies (made in compliance with regulations) to serve as } \\
\text { approved substitutes for original records destroyed in accordance } \\
\text { with official authorizations shall have the same effect as the } \\
\text { originals, and shall be treated as originals for the purpose of } \\
\text { admissibility in evidence (Title } 44 \text { USC, Sect. 3312; Title } 44 \text { USC } \\
\text { Sect. 2112). Conversion of documents, data, or information to a } \\
\text { microform medium does not imply any change in requirements to } \\
\text { comply with the provisions of the Privacy Act of } 1974 \text {. }\end{array}$ \\
\hline $\begin{array}{l}\text { OR } 1324.4 A, 12 / 5 / 84, \\
\text { Micrographics Management } \\
\text { Section } 5 b\end{array}$ & Appendix B-4 & Complete & $\begin{array}{l}\text { Comply with provisions of DOE } 1324.4 \mathrm{~A} \text {. (3) Develop and maintain } \\
\text { accurate and complete perpetual inventories of micrographics } \\
\text { production, reproduction, and display equipment. }\end{array}$ \\
\hline
\end{tabular}


Table 2 (continued)

\begin{tabular}{|c|c|c|c|}
\hline \multicolumn{3}{|c|}{ Administrative and technical basis } & \multirow[t]{2}{*}{ Leve 1 doamen mmber 10-101, Reconds Management, Rev. 2} \\
\hline Compliance document & $\begin{array}{c}\text { Level } 1 \\
\text { document section }\end{array}$ & Flowdown status & \\
\hline $\begin{array}{l}\text { DOE } 1324.2 \mathrm{~A}, 9 / 13 / 88 \\
\text { Records Disposition } \\
\text { Chap I, 2a }\end{array}$ & $\begin{array}{l}\text { Appendix B-3 } \\
\text { Inventory Action Plan }\end{array}$ & Compiete & $\begin{array}{l}\text { The first step in the disposition process is to inventory the files (both } \\
\text { record and nonrecord) in the organization. }\end{array}$ \\
\hline $\begin{array}{l}1324.2 A \\
\text { Chap I, } 26\end{array}$ & $\begin{array}{l}\text { Appendix B-3 } \\
\text { Also Inventory Action Plan }\end{array}$ & $\begin{array}{l}\text { Complete; Energy } \\
\text { Systems Records } \\
\text { Inventory and } \\
\text { Disposition Schedule } \\
\text { (RIDS) IDS database } \\
\text { prints out info in } \\
\text { correct format }\end{array}$ & $\begin{array}{l}\text { DOE F } 1324.10 \text {, "Records Inventory and Disposition Schedule," is } \\
\text { used to document the inventory. The blocks on the form pertaining } \\
\text { to disposition are completed later. }\end{array}$ \\
\hline $\begin{array}{l}\text { 1324.2A } \\
\text { Chap I, } 3\end{array}$ & $\begin{array}{l}\text { Appendix B-3 } \\
\text { Also Inventory Action Plan }\end{array}$ & Complete & $\begin{array}{l}\text { The completed inventory is reviewed to determine the proper } \\
\text { disposition authority for each filing series. }\end{array}$ \\
\hline 1324.2A, Chap I, 3a & $\begin{array}{l}\text { Appendix B-3 } \\
\text { Also Inventory Action Plan }\end{array}$ & Complete & Dispose of nonrecord material when no longer needed. \\
\hline 1324.2A, Chap I, 3b & $\begin{array}{l}\text { Appendix B-3 } \\
\text { Also Inventory Action Plan. }\end{array}$ & Complete & $\begin{array}{l}\text { Record material covered by GRS or DOERS. Compare filing series } \\
\text { with item descriptions in the schedules. Where they match closely } \\
\text { enough to determine coverage, the schedule and item number are } \\
\text { indicated in block } 7 \text { of DOE F } 1324.10 \text {. }\end{array}$ \\
\hline $\begin{array}{l}\text { 1324.2A } \\
\text { Chap I, 3c }\end{array}$ & $\begin{array}{l}\text { Appendix IB-3 } \\
\text { Also Inventory Action Plan }\end{array}$ & Complete & $\begin{array}{l}\text { Record material not covered by existing schedules. DOE F 1324.5, } \\
\text { "Request for Records Disposition Authority must be completed and } \\
\text { submitted through the appropriate records officers to MA-213.3. }\end{array}$ \\
\hline $\begin{array}{l}\text { 1324.2A } \\
\text { Chap I, } 4\end{array}$ & $\begin{array}{l}\text { Appendix B-3 } \\
\text { Inventory Action Plan }\end{array}$ & Complete & $\begin{array}{l}\text { Management Plans. DOE and contractor organizations must assure } \\
\text { all their records are inventoried and inventories kept current. } \\
\text { Planning for disposition must not be delayed waiting for completion } \\
\text { of the inventory of all records. The annual records management } \\
\text { plan must balance inventory and disposition efforts to maximize } \\
\text { benefits. }\end{array}$ \\
\hline
\end{tabular}


Table 2 (continued)

\begin{tabular}{|c|c|c|c|}
\hline \multicolumn{3}{|c|}{ Administrative and technical basis } & \multirow{2}{*}{ 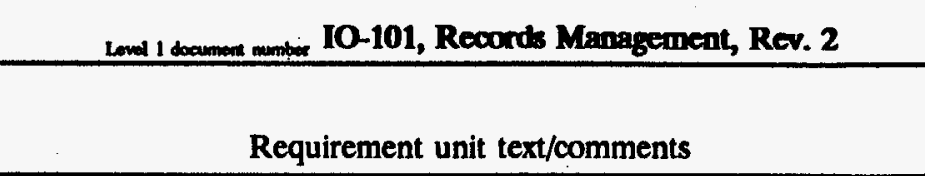 } \\
\hline Compliance document & $\begin{array}{c}\text { Level } 1 \\
\text { document section }\end{array}$ & Flowdown status & \\
\hline $\begin{array}{l}\text { 1324.2A } \\
\text { Chap I, } 5\end{array}$ & $\begin{array}{l}\text { D; Appendix B-3 } \\
\text { Also Inventory Action Plan }\end{array}$ & Complete & $\begin{array}{l}\text { Disposition actions include removing noncurrent files from high-cost } \\
\text { office space to local records holding areas and/or direct to the } \\
\text { servicing FRC; destroying records authorized under appropriate } \\
\text { schedules; or transferring them to the National Archives for } \\
\text { permanent storage. }\end{array}$ \\
\hline $\begin{array}{l}1324.2 \mathrm{~A} \\
\text { Chap I, 6a }\end{array}$ & $\begin{array}{l}\text { Appendix B-3, C-5; Section D; } \\
\text { Also Inventory Action Plan }\end{array}$ & Complete & $\begin{array}{l}\text { Electronic Records. ADP/electronic, machine-readable information } \\
\text { is included in the statutory definition of records. Such records are } \\
\text { described separately from hard copy records. This is done by } \\
\text { entering a separate subitem on the DOE F 1324.10 to show the } \\
\text { filing series is also in an electronic media (e.g., tape or disk). }\end{array}$ \\
\hline $\begin{array}{l}\text { 1324.2A } \\
\text { Chap I, 6b }\end{array}$ & Appendix C-6 & Complete & $\begin{array}{l}\text { Micrographics. Each project of significant size requires a cost-benefit } \\
\text { study to assure the project is clearly to the advantage of the Gov. } \\
\text { when purchase of a micrographic system is contemplated. Copies } \\
\text { have to be adequate substitutes for the hard copies they are } \\
\text { replacing, be readable and useable for the approved retention } \\
\text { periods of those hard copy records. Note that approval of NARA is } \\
\text { required if the project involves microfilming of permanent records. }\end{array}$ \\
\hline $\begin{array}{l}\text { 1324.2A } \\
\text { Chap I, } 6 \mathrm{c}-1\end{array}$ & $\begin{array}{l}\text { Appendix B-3 } \\
\text { Also Inventory Action Plan }\end{array}$ & Complete & $\begin{array}{l}\text { Classified Records Disposal. Classified records are scheduled just } \\
\text { like unclassified records. The disposition of accountable documents } \\
\text { involves special effort because of security requirements. Vigorous } \\
\text { efforts are to be made to assure compliance with disposition } \\
\text { authorities. Nonrecord and extra copies of classified documents are } \\
\text { promptly disposed of when no longer needed. DOE 5635.1A } \\
\text { contains the security requirements and procedures for these } \\
\text { documents. Classification of the records is to be indicated on the } \\
\text { DOE F 1324.10 to aid in complying with the procedures in DOE } \\
\text { 5635.1A. }\end{array}$ \\
\hline
\end{tabular}


Table 2 (continued)

\begin{tabular}{|c|c|c|c|}
\hline \multicolumn{3}{|c|}{ Administrative and technical basis } & \multirow[t]{2}{*}{ Lowi 1 doumenter IO-101, Reconds Management, Rev. 2} \\
\hline Compliance document & $\begin{array}{c}\text { Level } 1 \\
\text { document section }\end{array}$ & Flowdown status & \\
\hline $\begin{array}{l}\text { 1324.2A } \\
\text { Chap I, } 6 \mathrm{~d}-1\end{array}$ & $\begin{array}{l}\text { Appendix B-3 } \\
\text { Also Inventory Action Plan }\end{array}$ & Complete & $\begin{array}{l}\text { Unclassified, Sensitive Information. This category of records includes } \\
\text { Unclassified Controlled Nuclear Information (UNCI), Naval } \\
\text { Nuclear Propulsion Information, Export Controlled Information, } \\
\text { Official Use Only Information, and a variety of other sensitive } \\
\text { information on which controls area placed by organizations. No } \\
\text { attempt will be made to comply with the numerous requirements for } \\
\text { the handling, including special markings, of these records in records } \\
\text { holding areas or in FRCs. However, when these records are recalled } \\
\text { by their custodial office or organization it is incumbent on that } \\
\text { office to comply with the requirements in Departmental regulations } \\
\text { or directives, such as DOE } 5635.4 \text {. No action on these records will } \\
\text { be taken by records personnel. }\end{array}$ \\
\hline $\begin{array}{l}\text { 1324.2A } \\
\text { Chap II, 2a }\end{array}$ & $\begin{array}{l}\text { Appendix B-3 } \\
\text { Also Inventory Action Plan }\end{array}$ & Complete & $\begin{array}{l}\text { Inventory. The first step is to inventory the files of the } \\
\text { organizational unit which has custody of records. This unit is } \\
\text { identified by being a file station and by having a correspondence } \\
\text { symbol in Departmental organizations. The management and } \\
\text { operating contractor shouid use an appropriate designation. The } \\
\text { schedule as identified in Chapter } V \text { is the key to the disposition } \\
\text { program. }\end{array}$ \\
\hline $\begin{array}{l}\text { 1324.2A } \\
\text { Chap II, 2a (1) }\end{array}$ & $\begin{array}{l}\text { Appendix B-3 } \\
\text { Also Inventory Action Plan }\end{array}$ & Complete & $\begin{array}{l}\text { Characteristics of a Records Inventory. (a) It must cover all records } \\
\text { in the organizational unit. (b) Nonrecords material must be } \\
\text { included. (c) Filing series descriptions must be clear. (d) Records } \\
\text { must be listed by filing series (not document by document or folder } \\
\text { by folder). (e) Location, access restrictions, file indices are placed on } \\
\text { DOE F 1324.10. }\end{array}$ \\
\hline $\begin{array}{l}\text { 1324.2A } \\
\text { Chap II, 2a (2) (a) }\end{array}$ & $\begin{array}{l}\text { Appendix B-3 } \\
\text { Also Inventory Action Plan }\end{array}$ & Complete & $\begin{array}{l}\text { Organizational Unit Designation. Separate RIDS are prepared for } \\
\text { each file station. }\end{array}$ \\
\hline
\end{tabular}


Table 2 (continued)

\begin{tabular}{|c|c|c|c|}
\hline \multicolumn{3}{|c|}{ Administrative and technical besis } & \multirow[t]{2}{*}{ Lovel 1 dooment mumber 10-101, Reconds Management, Rev. 2} \\
\hline Compliance document & $\begin{array}{c}\text { Level } 1 \\
\text { document section }\end{array}$ & Flowdown status & \\
\hline $\begin{array}{l}1324.2 \mathrm{~A} \\
\text { Chap II, 2a (2) (b) }\end{array}$ & $\begin{array}{l}\text { Appendix B-3 } \\
\text { Also Inventory Action Plan }\end{array}$ & Complete & $\begin{array}{l}\text { Organizational Unit Designation. Responsibility for files } \\
\text { maintenance and disposition actions must be assigned to an } \\
\text { appropriate staff member. }\end{array}$ \\
\hline $\begin{array}{l}1324.2 \mathrm{~A} \\
\text { Chap II, 2a (3) }\end{array}$ & $\begin{array}{l}\text { Appendix B-3 } \\
\text { Also Inventory Action Plan }\end{array}$ & Complete & $\begin{array}{l}\text { Scope. The inventory covers all files of each file station and includes } \\
\text { the following: (a) Record and nonrecord material; (b) Classified, } \\
\text { controlled, and unclassified papers; (c) Machine-readable and } \\
\text { microfilm records; (d) Audiovisual records; (e) Filing series and } \\
\text { correspondence files; (f) Permanent as well as temporary records; } \\
\text { (g) References material (pamphlets, reports, extra file copies) } \\
\text { maintained in file equipment. }\end{array}$ \\
\hline $\begin{array}{l}\text { 1324.2A } \\
\text { Chap II, 2a (4) (a) }\end{array}$ & $\begin{array}{l}\text { Appendix B-3 } \\
\text { Also Inventory Action Plan }\end{array}$ & Complete & $\begin{array}{l}\text { Inventory items should be descriptive of filing series, not separate } \\
\text { forms, reports, file folders, or other papers which do no constitute } \\
\text { filing series. }\end{array}$ \\
\hline $\begin{array}{l}1324.2 A \\
\text { Chap II, 2a (4) (b) }\end{array}$ & $\begin{array}{l}\text { Appendix B-3 } \\
\text { Also Inventory Action Plan }\end{array}$ & Complete & $\begin{array}{l}\text { Inventory items should be limited to filing series, wherever possible. } \\
\text { They should not be expanded to include all of the records of an } \\
\text { activity unless all of the separate items are interfiled. }\end{array}$ \\
\hline $\begin{array}{l}1324.2 \mathrm{~A} \\
\text { Chap II, 2a (5) (a) }\end{array}$ & $\begin{array}{l}\text { Appendix B-3 } \\
\text { Also Inventory Action Plan }\end{array}$ & Complete & $\begin{array}{l}\text { It is essential that the records in the inventory be described in terms } \\
\text { that will be meaningful to the person who will apply the schedule. }\end{array}$ \\
\hline $\begin{array}{l}1324.2 \mathrm{~A} \\
\text { Chap II 2b (1) (a) }\end{array}$ & $\begin{array}{l}\text { Appendix B-3 } \\
\text { Also Inventory Action Plan }\end{array}$ & Complete & $\begin{array}{l}\text { Review of Inventory. The completed inventory is reviewed to } \\
\text { determine the proper disposition of the items described therein. }\end{array}$ \\
\hline $\begin{array}{l}1324.2 \mathrm{~A} \\
\text { Chap II, 2b (1) (b) }\end{array}$ & $\begin{array}{l}\text { Appendix B-3 } \\
\text { Also Inventory Action Plan }\end{array}$ & Complete & $\begin{array}{l}\text { Review of Inventory. Record items in the inventory, which are } \\
\text { covered by existing records schedules, are identified by matching the } \\
\text { items on the inventory with appropriate records descriptions in the } \\
\text { GRS or DOERS. }\end{array}$ \\
\hline
\end{tabular}


Table 2 (continued)

\begin{tabular}{|c|c|c|c|}
\hline \multicolumn{3}{|c|}{ Administrative and technical besis } & \multirow[t]{2}{*}{ 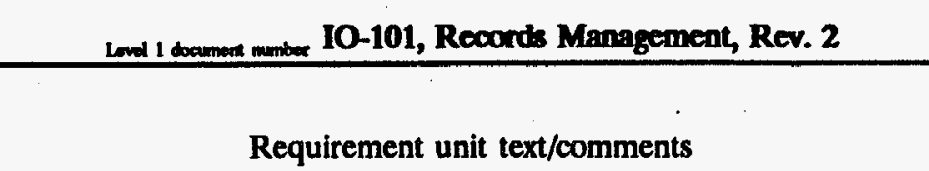 } \\
\hline Compliance document & $\begin{array}{c}\text { Level } 1 \\
\text { document section }\end{array}$ & Flowdown status & \\
\hline $\begin{array}{l}\text { 1324.2A } \\
\text { Chap II, 2b (2) }\end{array}$ & $\begin{array}{l}\text { Appendix B-3 } \\
\text { Also Inventory Action Plan }\end{array}$ & Compiete & $\begin{array}{l}\text { Use of Schedules. The GRS and DOERS apply to records in the } \\
\text { custody of M\&O contractors and the Department. The DOERS } \\
\text { contain NARA approved disposition authorizations on records } \\
\text { unique to DOE. When records are created which are not described } \\
\text { in the GRS or DOERS, their creator is responsible for initiating } \\
\text { action to obtain their authorization for disposition. The appropriate } \\
\text { records officer should be contacted when any doubt arises on their } \\
\text { use. }\end{array}$ \\
\hline $\begin{array}{l}\text { 1324.2A } \\
\text { Chap II, 2b (4) (a) }\end{array}$ & $\begin{array}{l}\text { Appendix B-3; Section D } \\
\text { Also Inventory Action Plan }\end{array}$ & Complete & $\begin{array}{l}\text { The periods stated in the authorized disposition column are the } \\
\text { minimum periods of time which records must be retained. Records } \\
\text { may not be destroyed until after the elapse of the periods specified, } \\
\text { or in some cases, until the occurrence of a specified event. }\end{array}$ \\
\hline $\begin{array}{l}\text { 1324.2A } \\
\text { Chap II, 2b (4) (b) }\end{array}$ & $\begin{array}{l}\text { Appendix B-3 } \\
\text { Also Inventory Action Plan }\end{array}$ & Complete & $\begin{array}{l}\text { Occasionally, it may be necessary to establish longer or shorter } \\
\text { periods than prescribed in the records schedules. If the criteria on } \\
\text { which the disposition was originally based have changed, a DOE F } \\
1324.5 \text { should be prepared giving the reason for the change. The } \\
\text { form is forwarded by the headquarters or field organization Records } \\
\text { Officer to the Information Management Branch after proper } \\
\text { coordination at the local level. }\end{array}$ \\
\hline $\begin{array}{l}\text { 1324.2A } \\
\text { Chap II, 2b (4) (c) }\end{array}$ & N/A & N/A & $\begin{array}{l}\text { MA-213.3 will obtain NARA Vother approvals. Extensions of over } 1 \\
\text { year require HQ and NARA approvals. Such data is part of the } \\
\text { management plan. }\end{array}$ \\
\hline $\begin{array}{l}\text { 1324.2A } \\
\text { Chap II, 2b (4) (d) }\end{array}$ & $\begin{array}{l}\text { Appendix B-3 } \\
\text { Also Inventory Action Plan }\end{array}$ & Complete & $\begin{array}{l}\text { If Federal or State laws, or regulations issued thereunder, require } \\
\text { specific retention periods, those periods are entered on the RIDS. } \\
\text { This requirement shall not be construed as directing the extension of } \\
\text { records retention standards to coincide with statutes of limitations in } \\
\text { the various states. }\end{array}$ \\
\hline
\end{tabular}


Table 2 (continued)

\begin{tabular}{|c|c|c|c|}
\hline \multicolumn{3}{|c|}{ Administrative and technical besis } & \multirow[t]{2}{*}{ Lewd 1 docament member IO-101, Reconds Management, Rev. 2} \\
\hline Compliance document & $\begin{array}{c}\text { Level } 1 \\
\text { document section }\end{array}$ & Flowdown status & \\
\hline $\begin{array}{l}1324.2 \mathrm{~A} \\
\text { Chap 2b (5) (a) }\end{array}$ & $\begin{array}{l}\text { Appendix B-3 } \\
\text { Also Inventory Action Plan }\end{array}$ & Complete & $\begin{array}{l}\text { Each nonrecord filing series is designated on RIDS by entering } \\
\text { "nonrecord" in column 7, Disposition Authority. If the determination } \\
\text { of nonrecord is based on physical duplication, also indicate the office } \\
\text { responsible for keeping the record copy. }\end{array}$ \\
\hline $\begin{array}{l}\text { 1324.2A } \\
\text { Chap II, 2b (5) (b) }\end{array}$ & $\begin{array}{l}\text { Appendix B-3 } \\
\text { Also Inventory Action Plan }\end{array}$ & Complete & $\begin{array}{l}\text { Non record items are evaluated to determine appropriate disposal } \\
\text { times. The disposal dates are posted in column } 8 \text { of RIDS. } \\
\text { Nonrecord material may be disposed of without NARA or other } \\
\text { authority. }\end{array}$ \\
\hline $\begin{array}{l}1324.2 \mathrm{~A} \\
\text { Chap II, 2b (6) }\end{array}$ & $\begin{array}{l}\text { Appendix B-3 } \\
\text { Also Inventory Action Plan }\end{array}$ & Complete & $\begin{array}{l}\text { Filing Series Not Covered by Approved Schedules. For these filing } \\
\text { series, new records retention standards need to be developed. The } \\
\text { entry "to be obtained" is posted in column } 7 \text { of RIDS and "to be } \\
\text { developed" in column } 8 \text {. }\end{array}$ \\
\hline $\begin{array}{l}\text { 1324.2A } \\
\text { Chap II, 2b (7) }\end{array}$ & $\begin{array}{l}\text { Appendix B-3 } \\
\text { Also Inventory Action Plan }\end{array}$ & Complete & $\begin{array}{l}\text { Cutoff Instructions and Retirement Periods. The completed RIDS } \\
\text { includes a timetable for the removal of noncurrent records from } \\
\text { office space and equipment and transfer to lower cost storage DOE } \\
\text { facilities. This timetable provides instructions for file cutoff, } \\
\text { retirement, transfer, or destruction. Retirement and transfer periods } \\
\text { are developed only after the disposition is determined, since usually } \\
\text { a significant part of each collection of records can be destroyed in } \\
\text { the organization responsible for them. The instructions for file } \\
\text { cutoff, retirement, transfer, or destruction are posted in column } 9 \text { of } \\
\text { the RIDS, after which the RIDS is ready for preparation in final } \\
\text { form, approval, and application. }\end{array}$ \\
\hline $\begin{array}{l}1324.2 \mathrm{~A} \\
\text { Chap II, 2c (1) }\end{array}$ & $\begin{array}{l}\text { Appendix B-3 } \\
\text { Also Inventory Action Plan }\end{array}$ & Complete & $\begin{array}{l}\text { Discontinued filing series should be listed on a separate continuation } \\
\text { sheet for removal from RIDS when all of the discontinued records } \\
\text { have been disposed of. Likewise deferred or open items (ones for } \\
\text { which new added authorizations are needed) may be listed on a } \\
\text { separate sheet since that part of the RIDS is not subject to } \\
\text { immediate application. }\end{array}$ \\
\hline
\end{tabular}


Table 2 (continued)

\begin{tabular}{|c|c|c|c|}
\hline \multicolumn{3}{|c|}{ Administrative and technical basis } & \multirow[t]{2}{*}{ Level 1 docamerar number 10-101, Records Management, Rev. 2} \\
\hline Compliance document & $\begin{array}{c}\text { Level } 1 \\
\text { document section }\end{array}$ & Flowdown status & \\
\hline $\begin{array}{l}\text { 1324.2A } \\
\text { Chap II, 2c (2) }\end{array}$ & N/A & N/A & $\begin{array}{l}\text { The Office of Administration Services (MA-23) prescribes the } \\
\text { procedures for approval of RIDS at headquarters. }\end{array}$ \\
\hline $\begin{array}{l}1324.2 \mathrm{~A} \\
\text { Chap II, 2c (3) }\end{array}$ & $\begin{array}{l}\text { Appendix B-3 } \\
\text { Also Inventory Action Plan }\end{array}$ & Complete & $\begin{array}{l}\text { Each field organization and each contractor prescribes procedures } \\
\text { for approval of RIDS within their own organizations. }\end{array}$ \\
\hline $\begin{array}{l}1324.2 \mathrm{~A} \\
\text { Chap II, 2c (4) }\end{array}$ & $\begin{array}{l}\text { Appendix B-3 } \\
\text { Also Inventory Action Plan }\end{array}$ & Complete & $\begin{array}{l}\text { Approvals required should be limited to organizations having a } \\
\text { legitimate interest in the records. Approval by the Information } \\
\text { Management Branch, MA-213.3, is not required. }\end{array}$ \\
\hline $\begin{array}{l}\text { 1324.2A } \\
\text { Chap II, } 2 c(4)(a, b)\end{array}$ & $\begin{array}{l}\text { Appendix B-3 } \\
\text { Also Inventory Action Plan }\end{array}$ & $\begin{array}{l}\text { Waiver submitted on } \\
2 c(4)(a) \text { during } \\
\text { Assessment. RAD } \\
\text { maintains the master } \\
\text { copy as a requirement } \\
\text { of the systems } \\
\text { development. File } \\
\text { custodians receive a } \\
\text { clean copy for their } \\
\text { files. }\end{array}$ & $\begin{array}{l}\text { RIDS should be prepared in at least } 2 \text { copies for distribution and } \\
\text { use. The originals should be given to files custodians responsible for } \\
\text { applying RIDS. One copy should be maintained by the local records } \\
\text { officer, or other official responsible for the records disposition } \\
\text { program of the organization. The RIDS is a key document in the } \\
\text { records management plan. }\end{array}$ \\
\hline $\begin{array}{l}\text { 1324.2A } \\
\text { Chap II, 2d (1) }\end{array}$ & $\begin{array}{l}\text { D-1; Appendix B-3,4 } \\
\text { Energy Systems Directive to } \\
\text { site/major organization records } \\
\text { managers }\end{array}$ & Complete & $\begin{array}{l}\text { The approved RIDS is the basic document in the management plan. } \\
\text { They are to be reviewed, analyzed, and complied at records officer } \\
\text { level, i.e., each Departmental and M\&O contractor records officer } \\
\text { will have a plan for their records management activities, based on } \\
\text { the RIDS. }\end{array}$ \\
\hline
\end{tabular}


Table 2 (continued)

\begin{tabular}{|c|c|c|c|}
\hline \multicolumn{3}{|c|}{ Administrative and technical besis } & \multirow{2}{*}{$\begin{array}{l}\text { Lewal } 1 \text { document member 10-101, Reconds Management, Rev. } 2 \\
\text { Requirement unit text/comments }\end{array}$} \\
\hline Compliance document & $\begin{array}{l}\text { Level } 1 \\
\text { document section }\end{array}$ & Flowdown status & \\
\hline $\begin{array}{l}\text { 1324.2A } \\
\text { Chap II, 2d (2) }\end{array}$ & $\begin{array}{l}\text { D; Appendix B-3 } \\
\text { Also Inventory Action Plan }\end{array}$ & Complete & $\begin{array}{l}\text { Some considerations in using RIDS: (a)Records are to be disposed } \\
\text { of no later than } 1 \text { year from their disposal dates (b) Nonrecord } \\
\text { material should be disposed of prior to but no later than the } \\
\text { scheduled disposal date (c) Disposal and transfer of inactive records } \\
\text { are accomplished on a regular basis (d) An expedited timetable is } \\
\text { necessary if records accumulate rapidly (e) Given careful planning, } \\
\text { actions under the management plan are scheduled as much as } \\
\text { possible so as not to interfere with current operations. }\end{array}$ \\
\hline $\begin{array}{l}\text { 1324.2A } \\
\text { Chap II, 2e (1) (a) }\end{array}$ & $\begin{array}{l}\text { Appendix B-3; Section D } \\
\text { Also Inventory Action Plan }\end{array}$ & Partial & $\begin{array}{l}\text { Method. Unclassified records are disposed of by maceration, } \\
\text { shredding, landfill, burial, or by sale as waste paper. Privileged } \\
\text { records shall be shredded, macerated or otherwise rendered illegible. } \\
\text { Contracts for the sale of reconds as waste paper shall contain a } \\
\text { provision prohibiting their resale or use as records or documents. }\end{array}$ \\
\hline $\begin{array}{l}\text { 1324.2A } \\
\text { Chap II, 2e (1) (b) } 1\end{array}$ & $\begin{array}{l}\text { Appendix B-3; Section D-3 } \\
\text { Also Inventory Action Plan }\end{array}$ & Complete & $\begin{array}{l}\text { Method. All classified and controlled records shall be disposed of in } \\
\text { accordance with security regulations. }\end{array}$ \\
\hline $\begin{array}{l}1324.2 \mathrm{~A} \\
\text { Chap II, 2e (2) }\end{array}$ & $\begin{array}{l}\text { Appendix B-3 } \\
\text { Also Inventory Action Plan }\end{array}$ & Complete & $\begin{array}{l}\text { Responsibility. The responsibility for authorizing the physical } \\
\text { disposal of records belongs to the original office of custody which is } \\
\text { notified by the local records holding area or the FRC where the } \\
\text { records are stored when they are eligible for disposal. At this time } \\
\text { the original office of custody authorizes their disposal, or through } \\
\text { the appropriate DOE records officer, justifies deferral. }\end{array}$ \\
\hline
\end{tabular}


Table 2 (continued)

\begin{tabular}{|c|c|c|c|}
\hline \multicolumn{3}{|c|}{ Administrative and technical basis } & \multirow{2}{*}{$\begin{array}{l}\text { Lovel } 1 \text { doameax ment101, Records Management, Rev. } 2 \\
\text { Requirement unit text/comments }\end{array}$} \\
\hline Compliance document & $\begin{array}{c}\text { Level } 1 \\
\text { document section }\end{array}$ & Flowdown status & \\
\hline $\begin{array}{l}\text { 1324.2A } \\
\text { Chap II, 2f }\end{array}$ & $\begin{array}{l}\text { Section D-3; Appendix B-3 } \\
\text { Also Inventory Action Plan }\end{array}$ & Complete & $\begin{array}{l}\text { Deferred Disposal. Records pertaining to current or pending } \\
\text { litigation and investigation, pending Freedom of Information Act } \\
\text { matters or to exceptions taken by the General Accounting Office } \\
\text { (GAO) shall be retained until the litigation is settled, the Freedom } \\
\text { of Information Act matter resolved, or the GAO exception is } \\
\text { cleared. If such cases exist, and involve records otherwise eligible for } \\
\text { disposal, the specific records should be removed from the filing } \\
\text { series and retained in a suspense file until the matter of controversy } \\
\text { is settled. }\end{array}$ \\
\hline $\begin{array}{l}\text { 1324.2A } \\
\text { Chap III, } 2\end{array}$ & $\begin{array}{l}\text { Appendix B-3 } \\
\text { Also Inventory Action Plan }\end{array}$ & Complete & $\begin{array}{l}\text { Existing Standards. The GRS and DOERS often provide practical } \\
\text { guidance in developing disposition authorization for similar or } \\
\text { related records. They should be used in the appraisal process to } \\
\text { maintain consistency. }\end{array}$ \\
\hline $\begin{array}{l}\text { 1324.2A } \\
\text { Chap III, } 4 \mathrm{~b}\end{array}$ & N/A & $\begin{array}{l}\text { N/A Pertains to DOE } \\
\text { Field Offices } \\
\text { per RU assessment }\end{array}$ & $\begin{array}{l}\text { Proposed disposition for financial records created by contractors are } \\
\text { submitted to the GAO for concurrence. }\end{array}$ \\
\hline $\begin{array}{l}\text { 1324.2A } \\
\text { Chap III, 4c }\end{array}$ & $\begin{array}{l}\text { Appendix B-3 } \\
\text { Also Inventory Action Plan }\end{array}$ & Complete & $\begin{array}{l}\text { All GRS dispositions are mandatory unless NARA approves an SF } \\
115 \text { for individual deviations. }\end{array}$ \\
\hline $\begin{array}{l}\text { 1324.2A } \\
\text { Chap IV, 2a }\end{array}$ & $\begin{array}{l}\text { Appendix B-3 } \\
\text { Also Inventory Action Plan; } \\
\text { Site Record Center Procedures }\end{array}$ & Complete & $\begin{array}{l}\text { Requests for reference service directed to a FRC should be made } \\
\text { by a specific individual or designee authorized to do so by the } \\
\text { Director of Administrative Services or Heads of Field Organizations, } \\
\text { as appropriate. Routine requests are made in writing using Optional } \\
\text { Form 11, "Reference Request-Federal Records Centers." Priority or } \\
\text { emergency requests may be made by telephone or teletype. } \\
\text { Requests must provide information such as the Records Group } \\
\text { Number, FRC Accession Number, date(s), and descriptions of the } \\
\text { desired records, to facilitate retrieval. }\end{array}$ \\
\hline
\end{tabular}


Table 2 (continued)

\begin{tabular}{|c|c|c|c|}
\hline \multicolumn{3}{|c|}{ Administrative and toctinical basis } & \multirow[t]{2}{*}{ Lovel 1 docameat member 10-101, Records Management, Rev. 2} \\
\hline Compliance document & $\begin{array}{c}\text { Level } 1 \\
\text { document section }\end{array}$ & Flowdown status & \\
\hline $\begin{array}{l}\text { 1324.2A } \\
\text { Chap IV, 2c }\end{array}$ & $\begin{array}{l}\text { Appendix B-3 } \\
\text { Also Inventory Action Plan }\end{array}$ & Complete & $\begin{array}{l}\text { Record group numbers are assigned to Federal agencies by the } \\
\text { Assistant Archivist for the National Archives to be used for } \\
\text { identification and control purposes in transferring concurrent } \\
\text { records to FRCs. The appropriate record group number must be } \\
\text { shown in column } 6 \text { (a) of the Standard Form } 135 \text { covering each } \\
\text { transfer of records to an FRC. }\end{array}$ \\
\hline $\begin{array}{l}\text { 1324.2A } \\
\text { Chap IV, 2e }\end{array}$ & $\begin{array}{l}\text { Appendix B-3 } \\
\text { Also Inventory Action Plan }\end{array}$ & Complete & Coordinate with appropriate FRC to schedule those transfers. \\
\hline $\begin{array}{l}\text { 1324.2A } \\
\text { Chap IV, } 3\end{array}$ & $\begin{array}{l}\text { Appendix B-3 } \\
\text { Also Inventory Action Plan }\end{array}$ & Complete & $\begin{array}{l}\text { Transfer to Local Records Holding Areas. HQ and Field Records } \\
\text { Officers establish and implement transfer procedures to local } \\
\text { records holding areas under their control. }\end{array}$ \\
\hline $\begin{array}{l}\text { 1324.2A } \\
\text { Chap IV, } 4\end{array}$ & $\begin{array}{l}\text { Appendix B-3 } \\
\text { Also Inventory Action Plan }\end{array}$ & Complete & $\begin{array}{l}\text { Transfer to the National Archives. This transfer pertains only to } \\
\text { permanent records, and is documented in Standard Form } 258 \text {. If } \\
\text { such transfers are under consideration, the Departmental Records } \\
\text { Officer must be contacted for assistance and approvals. }\end{array}$ \\
\hline $\begin{array}{l}\text { 1324.2A } \\
\text { Chap V, } 2\end{array}$ & $\begin{array}{l}\text { Appendix B-3 } \\
\text { Also Inventory Action Plan }\end{array}$ & Complete & $\begin{array}{l}\text { Citations of Authorized Dispositions. In disposition actions regarding } \\
\text { these records, cite DOE and the schedule and item number as } \\
\text { follows; DOE } 1,1 \text { to reflect the authorized disposition under DOE } \\
\text { Schedule } 1 \text {, item } 1 \text {. The GRS is cited the same way. }\end{array}$ \\
\hline $\begin{array}{l}\text { OR 1324.2B, 9/11/89, Records } \\
\text { Disposition }\end{array}$ & $\begin{array}{l}\text { Appendix B-3 } \\
\text { Also Inventory Action Plan }\end{array}$ & Complete & $\begin{array}{l}\text { General: This order assigns OR responsibilities and prescribes OR } \\
\text { policies/procedures for the disposition of OR records. }\end{array}$ \\
\hline $\begin{array}{l}\text { DOE N 1324.13, 11/9/92, } \\
\text { Disposition of Personal Papers } \\
\text { and Official Records; Policy } 6 a\end{array}$ & B-2,3; C-7; Appendix D & Complete & $\begin{array}{l}\text { Summary: Sensitive classified and unclassified information (including } \\
\text { extra copies) is the property of US Government and may not be } \\
\text { removed from the Government's control by any agency's } \\
\text { departing/terminated official/employee. }\end{array}$ \\
\hline
\end{tabular}


Table 2 (continued)

\begin{tabular}{|c|c|c|c|}
\hline \multicolumn{3}{|c|}{ Administrative and technical basis } & \multirow[t]{2}{*}{ Level 1 docamana member IO-101, Records Management, Rev. 2} \\
\hline Compliance document & $\begin{array}{l}\text { Level } 1 \\
\text { document section }\end{array}$ & Flowdown status & \\
\hline $\begin{array}{l}\text { DOE Order } 1322.2 \mathrm{C}, 10 / 22 / 91 \text {, } \\
\text { Forms Management, } 9 \mathrm{~b}(2)(\mathrm{a})\end{array}$ & Appendix B-4 & $\begin{array}{l}\text { Partial; current } \\
\text { practices meet intent; } \\
\text { Energy Systems level } \\
\text { forms procedure } \\
\text { under development }\end{array}$ & $\begin{array}{l}\text { Establish and maintain a forms management program that complies } \\
\text { with DOE and GSA objectives, requirements, and standards. }\end{array}$ \\
\hline $1322.2 \mathrm{C}, 9 \mathrm{~b}(2)(\mathrm{b})$ & Appendix B-4 & Complete & $\begin{array}{l}\text { Designate a Forms Manager to serve as a focal point for } \\
\text { coordination of activities pertaining to the forms management } \\
\text { program. }\end{array}$ \\
\hline $\begin{array}{l}\text { 1322.3C, } 11 / 29 / 89, \text { Directory of } \\
\text { Department Forms }\end{array}$ & Appendix B-4 & $\begin{array}{l}\text { Most of the forms are } \\
\text { DOE specific and } \\
\text { would not apply to } \\
\text { Energy Systems. }\end{array}$ & $\begin{array}{l}\text { Lists Headquarters and Departmental forms approved for use by } \\
\text { DOE. }\end{array}$ \\
\hline $\begin{array}{l}\text { 1322.4B, 12/12/89, Directory of } \\
\text { Standard, Optional and Other } \\
\text { Agency Forms }\end{array}$ & Appendix B-4 & $\begin{array}{l}\text { Most of the forms are } \\
\text { DOE specific and } \\
\text { would not apply to } \\
\text { Energy Systems. }\end{array}$ & $\begin{array}{l}\text { Lists forms, other than Headquarters and Departmental, that are } \\
\text { used by DOE }\end{array}$ \\
\hline $\begin{array}{l}\text { LEG-13, 6/8/92, Records } \\
\text { Management, V. A }\end{array}$ & B; Appendixes C-3,4 & Complete & $\begin{array}{l}\text { In implementing its records management program, each operating } \\
\text { element will: } \\
\text { A. Identify, list, and protect vital records. Duplicate such records } \\
\text { when possible. }\end{array}$ \\
\hline LEG-13, V. B. & $\begin{array}{l}\text { Sections A,B,C,D,E } \\
\text { Appendixes B, C }\end{array}$ & Complete & $\begin{array}{l}\text { Identify and protect company-sensitive records in accordance with } \\
\text { applicable operating instructions and internal procedures. }\end{array}$ \\
\hline
\end{tabular}


Table 2 (continued)

\begin{tabular}{|c|c|c|c|}
\hline \multicolumn{3}{|c|}{ Administrative and technical basis } & \multirow[t]{2}{*}{ 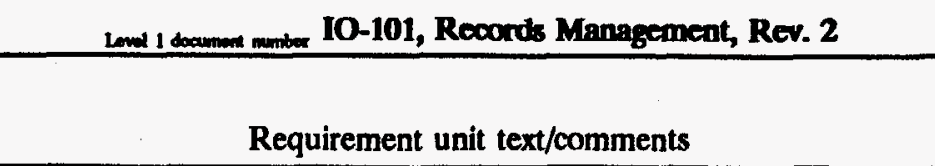 } \\
\hline Compliance document & $\begin{array}{c}\text { Level } 1 \\
\text { document section }\end{array}$ & Flowdown status & \\
\hline LEG-13, V. C & $\begin{array}{l}\text { Appendix B-4; Implementation } \\
\text { Plan for } 1324.5 \mathrm{~A}\end{array}$ & Complete & $\begin{array}{l}\text { Appoint a records manager responsible for establishing and } \\
\text { maintaining the element's records management program, and for } \\
\text { safeguarding all inactive records from the time they are consigned to } \\
\text { the records center through their final disposition. Appoint records } \\
\text { administrators responsible for controlling records for a function, } \\
\text { department, or program. }\end{array}$ \\
\hline LEG-13, V. D. & Appendix B-4 & Complete & $\begin{array}{l}\text { Implement programs to train new records managers and } \\
\text { administrators, and to periodically apprise records management } \\
\text { personnel of changes in the records management program. }\end{array}$ \\
\hline LEG-13, V. E. & $\begin{array}{l}\text { D-1 } \\
\text { Appendix B-3 }\end{array}$ & Complete & $\begin{array}{l}\text { Develop a records retention schedule which is responsive to } \\
\text { regulatory, Corporate, and operating element requirements, and } \\
\text { retain records accordingly. The retention schedule must, as a } \\
\text { minimum, include the following for each listed record: } \\
\text { 1. Number, name and brief description. } \\
\text { 2. Floor retention requirements and total retention requirements } \\
\text { stated in years and/or by event (e.g., until final purchase order } \\
\text { payment, until equipment is taken out of service, } 4 \text { years after final } \\
\text { payment). } \\
\text { 3. Authorization for retention: The number of the regulation, } \\
\text { operating instruction or operating element policy or procedure which } \\
\text { contains the retention requirements. If none of the former, the } \\
\text { cognizant department head or designee must sign/initial and date } \\
\text { the schedule, authorizing the retention requirements. }\end{array}$ \\
\hline LEG-13, V. F & Section C- 9-15; Appendix B-3 & Complete & $\begin{array}{l}\text { Establish records center(s) on- or off-site for the storage, control } \\
\text { and protection of inactive records. Ensure that each center provides } \\
\text { reasonable safeguards against potential perils such as fire, water } \\
\text { damage, rodent or insect infestation, theft, and floods; and } \\
\text { implements security control which prevent unauthorized use, } \\
\text { disclosure, and/or destruction of records. }\end{array}$ \\
\hline
\end{tabular}


Table 2 (continued)

\begin{tabular}{|c|c|c|c|}
\hline \multicolumn{3}{|c|}{ Administrative and tocthnical basis } & \multirow{2}{*}{ 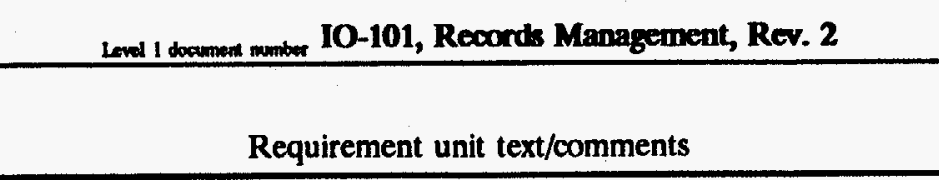 } \\
\hline Compliance document & $\begin{array}{c}\text { Level } 1 \\
\text { document section }\end{array}$ & Flowdown status & \\
\hline LEG-13, V.G. & $\begin{array}{l}\text { Section C-12,14; D; Appendix } \\
\text { B-3 }\end{array}$ & Complete & $\begin{array}{l}\text { Develop formal controls for records transmittal to, and } \\
\text { management, retrieval and destruction of inactive records consigned } \\
\text { to the records center. }\end{array}$ \\
\hline LEG-13, V. H. & Section C-3; Appendix B-2 & Complete & $\begin{array}{l}\text { Wherever possible, use computer-based tools to manage records } \\
\text { storage and retrieval, and micrographic equipment and techniques } \\
\text { for records storage. }\end{array}$ \\
\hline LEG-13, V. I. & Section A-1 & Complete & $\begin{array}{l}\text { To the extent possible, ensure that records do not contain personal } \\
\text { notations. }\end{array}$ \\
\hline LEG-13, V. J. & Section A-3; Appendix B-1 & Complete & $\begin{array}{l}\text { Ensure that records which must be retained after a program has } \\
\text { been concluded are administratively turned over to the general staff } \\
\text { of the appropriate function, such as Product Assurance or Technical } \\
\text { Operations, who will be responsible for the maintenance of those } \\
\text { records in accordance with this directive, the element's records } \\
\text { retention schedule, and contract requirements. }\end{array}$ \\
\hline LEG-13, V. K & Section C-7 & Complete & $\begin{array}{l}\text { Ensure that transferring or terminating personnel convey records for } \\
\text { which they are responsible to other appropriate company employees, } \\
\text { and that records are not removed from company premises or } \\
\text { destroyed without proper authorization. }\end{array}$ \\
\hline LEG-13, VI. A & $\begin{array}{l}\text { Section D; C-14 } \\
\text { Appendix B-3 }\end{array}$ & Complete & $\begin{array}{l}\text { SCREENING. At least annually, records used in current operations } \\
\text { will be screened, and designated as active or inactive. Duplicate } \\
\text { inactive records which serve no useful purpose will be destroyed. } \\
\text { Inactive records will be identified, given a specific destruction date in } \\
\text { accordance with the element's retention schedule, and placed in the } \\
\text { records center. }\end{array}$ \\
\hline LEG-13, VI. B. & Section C-15; Appendix B-3 & Complete & $\begin{array}{l}\text { STORAGE OF INACTIVE RECORDS. Records center personnel } \\
\text { will assign a storage code, log, and store the records, and ensure } \\
\text { that they may be readily retrieved. }\end{array}$ \\
\hline
\end{tabular}


Table 2 (continued)

\begin{tabular}{|c|c|c|c|}
\hline \multicolumn{3}{|c|}{ Administrative and technical basis } & \multirow{2}{*}{ 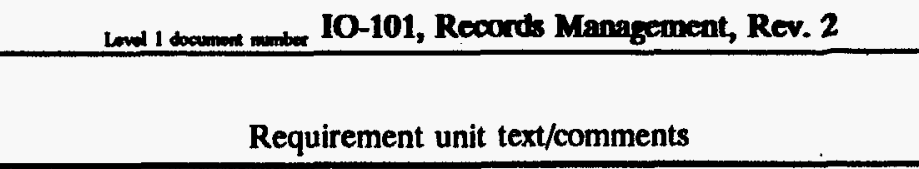 } \\
\hline Compliance document & $\begin{array}{c}\text { Level } 1 \\
\text { document section }\end{array}$ & Flowdown status & \\
\hline LEG-13, VI. C. & Section C; Appendixes B-2,3 & Complete & $\begin{array}{l}\text { RETRIEVAL OF INACTIVE RECORDS. Only records } \\
\text { management personnel and records administrators will have access } \\
\text { to stored records. Only the responsible records administrator may } \\
\text { authorize the retrieval of records belonging to a given function, } \\
\text { program or department. }\end{array}$ \\
\hline LEG-13, VI.D & Section D-3; Appendix B-3 & Partial & $\begin{array}{l}\text { AUTHORIZATION FOR DESTRUCTION. Prior to authorizing } \\
\text { destruction of active records, the responsible records administrator } \\
\text { may authorize the retrieval of records belonging to a given function, } \\
\text { program or department. } \\
\text { Six months prior to the scheduled destruction date assigned to } \\
\text { inactive records in storage in the records center, the Business } \\
\text { Operations, Tax, Legal, and consigning departments (and, when } \\
\text { appropriate the Environmental Manager or designee) must sign an } \\
\text { authorization for destruction of the records. Any records not } \\
\text { authorized for destruction must be assigned a new destruction date } \\
\text { per the operating element's retention schedule, returned to records } \\
\text { center storage, and remain under control of the department(or } \\
\text { environmental manager or designee) which assigned the revised } \\
\text { destruction date, until authorized for destruction. }\end{array}$ \\
\hline LEG-13, VI. E. & $\begin{array}{l}\text { Section D-3 } \\
\text { Appendix B-3 }\end{array}$ & Complete & $\begin{array}{l}\text { DESTRUCTION. The records managet must ensure that only } \\
\text { those records which are properly authorized for destruction are } \\
\text { destroyed. All paper records authorized for destruction will be } \\
\text { destroyed by incineration or shredding. Consideration should be } \\
\text { given to the recycling of shredded records. }\end{array}$ \\
\hline
\end{tabular}


Table 2 (continued)

\begin{tabular}{|c|c|c|c|}
\hline \multicolumn{3}{|c|}{ Administrative and technical besis } & \multirow[t]{2}{*}{ Level 1 documen mumber 10-101, Reconds Management, Rev. 2} \\
\hline Compliance document & $\begin{array}{c}\text { Level } 1 \\
\text { document section }\end{array}$ & Flowdown status & \\
\hline & $\begin{array}{l}\text { ESS-QA-17.0, 11/22/91, Quality } \\
\text { Assurance Records V B }\end{array}$ & $\begin{array}{l}\text { Complete } \\
\text { Sections A; B; C; D; } \\
\text { E }\end{array}$ & $\begin{array}{l}\text { Records that furnish physical evidence of the quality of an item, } \\
\text { product, process, structure, or facility or the qualifications of an } \\
\text { individual shall be maintained and shall contain sufficient } \\
\text { information to permit direct identification and traceability to the } \\
\text { facility or project they represent. Design specifications, procurement } \\
\text { documents, risk assessments, test procedures, inspection procedures, } \\
\text { and operating procedures shall specify the documents to be } \\
\text { generated, supplied, and maintained. }\end{array}$ \\
\hline & $\begin{array}{l}\text { ESS-QA-17.0 } \\
\text { V.C }\end{array}$ & $\begin{array}{l}\text { Complete } \\
\text { C-2; Appendix D }\end{array}$ & $\begin{array}{l}\text { Documents or other types of objective evidence shall be considered } \\
\text { valid records only if stamped, initialed, signed and dated, or } \\
\text { otherwise authenticated by authorized personnel. The authentication } \\
\text { may take the form of a statement by the designated responsible } \\
\text { individual or organization. Handwritten signatures are not required } \\
\text { if the document or objective evidence is clearly identified as a } \\
\text { statement by the reporting individual or organization. These records } \\
\text { may be originals or a legible reproduction. }\end{array}$ \\
\hline & $\begin{array}{l}\text { ESS-QA-17.0 } \\
\text { V. D. }\end{array}$ & $\begin{array}{l}\text { Complete } \\
\text { A, Entire procedure }\end{array}$ & $\begin{array}{l}\text { Records shall be distributed, handied, and controlled in accordance } \\
\text { with written procedures that contain enough detail to provide } \\
\text { guidance to fulfill the requirements for an acceptable records } \\
\text { system, as described herein. }\end{array}$ \\
\hline & $\begin{array}{l}\text { ESS-QA-17.0 } \\
\text { V.E. }\end{array}$ & $\begin{array}{l}\text { Complete } \\
\text { A-2 }\end{array}$ & $\begin{array}{l}\text { Recorded information written on a printed form shall be legible } \\
\text { using black or other suitable marking materials, of reproducible } \\
\text { microfilm quality, identifiable with unique identification for } \\
\text { traceability, and retrievable. }\end{array}$ \\
\hline & $\begin{array}{l}\text { ESS-QA-17.0 } \\
\text { V.F. }\end{array}$ & $\begin{array}{l}\text { Complete } \\
\text { Appendix C-5,6,7,8,9 }\end{array}$ & $\begin{array}{l}\text { Suitable backup copies shall be made and stored in separate } \\
\text { locations, or printed copies of the program or data shall be available } \\
\text { when recorded information is on magnetic media (computer disks, } \\
\text { tapes, or other formats. }\end{array}$ \\
\hline
\end{tabular}


Table 2 (continued)

\begin{tabular}{|c|c|c|c|}
\hline \multicolumn{3}{|c|}{ Administrative and tectinical basis } & \multirow[t]{2}{*}{ Lond 1 doament amber IO-101, Reconds Management, Rev. 2} \\
\hline Compliance document & $\begin{array}{c}\text { Level } 1 \\
\text { document section }\end{array}$ & Flowdown status & \\
\hline & $\begin{array}{l}\text { ESS-QA-17.0 } \\
\text { V.G. }\end{array}$ & $\begin{array}{l}\text { Complete } \\
\text { B } \\
\text { Appendixes B-3, D }\end{array}$ & $\begin{array}{l}\text { Lifetime records shall be maintained as record copies or stored for } \\
\text { future use (in accordance with DOE Order 1324.2) for the life of } \\
\text { the particular item, process, system, structure, or facility while it is } \\
\text { installed. }\end{array}$ \\
\hline & $\begin{array}{l}\text { ESS-QA-17.0 } \\
\text { V.H. }\end{array}$ & $\begin{array}{l}\text { Complete } \\
\text { B } \\
\text { Appendixes B-3,D }\end{array}$ & $\begin{array}{l}\text { Nonpermanent records shall be maintained as record copies (in } \\
\text { accordance with DOE Order 1324.2) for the retention period noted } \\
\text { on the document as specified on a data sheet or retention schedule. }\end{array}$ \\
\hline & $\begin{array}{l}\text { ESS-QA-17.0 } \\
\text { V.I. }\end{array}$ & $\begin{array}{l}\text { Complete } \\
\text { Appendix B-3 }\end{array}$ & $\begin{array}{l}\text { Government or other management directives may require that } \\
\text { certain lifetime or nonpermanent records be maintained for a longer } \\
\text { period than required by this standard. }\end{array}$ \\
\hline & $\begin{array}{l}\text { ESS-QA-17.0 } \\
\text { V.J. }\end{array}$ & $\begin{array}{l}\text { Complete } \\
\text { C-1; Appendix B-2 }\end{array}$ & $\begin{array}{l}\text { Records shall be corrected, modified, or amended in accordance } \\
\text { with procedures that prescribe the review and approval } \\
\text { requirements. The modifications or corrections shall include the date } \\
\text { and the identification of the person authorized to issue corrections } \\
\text { or modifications. }\end{array}$ \\
\hline & $\begin{array}{l}\text { ESS-QA-17.0 } \\
\text { V.K. }\end{array}$ & $\begin{array}{l}\text { Complete } \\
\text { C-12 }\end{array}$ & $\begin{array}{l}\text { Receipt control systems shall include the following as a minimum: } \\
\text { 1. method for designating the records, } \\
\text { 2. method for identifying records received, } \\
\text { 3. procedure for receiving and inspecting incoming records, } \\
\text { 4. method for submitting completed records to the storage facility, } \\
\text { and } \\
\text { 5. method or system for providing the current status of records } \\
\text { during the receiving process. }\end{array}$ \\
\hline
\end{tabular}


Table 2 (continued)

\begin{tabular}{|c|c|c|c|}
\hline \multicolumn{3}{|c|}{ Administrative and tochnical basis } & \multirow[t]{2}{*}{ Level 1 doament mumber 10-101, Reconds Management, Rev. 2} \\
\hline Compliance document & $\begin{array}{c}\text { Level } 1 \\
\text { document section }\end{array}$ & Flowdown status & \\
\hline & $\begin{array}{l}\text { ESS-QA-17.0 } \\
\text { V.L. }\end{array}$ & $\begin{array}{l}\text { Complete } \\
\text { C; Appendix B-2,3 }\end{array}$ & $\begin{array}{l}\text { Written storage procedures shall be prepared for both } \\
\text { nonpermanent and permanent (lifetime) storage before storage of } \\
\text { records. The procedure shall include the following as a minimum: } \\
\text { 1. description of the storage facility; } \\
\text { 2. filing system used; } \\
\text { 3. methods or procedures used to verify that the records received } \\
\text { are in agreement with the transmittal document and that the records } \\
\text { are legible or of a reproducible quality; } \\
\text { 4. rules governing access, control, and accountability for records } \\
\text { removed from the storage facility; } \\
\text { 5. method for filing supplemental information, additional records, } \\
\text { ore corrections, and } \\
\text { 6. identification of duplicate storage facility where applicable. }\end{array}$ \\
\hline & $\begin{array}{l}\text { ESS-QA-17.0 } \\
\text { V.M. }\end{array}$ & $\begin{array}{l}\text { Complete; } \\
\text { Appendixes B-3; C- } \\
5,6,7,8,9 \\
\text { Section C }\end{array}$ & $\begin{array}{l}\text { Record storage provisions shall apply as follows: } \\
\text { 1) The storage system shall provide conditions suitable for } \\
\text { preventing damage from moisture, temperature, pressure, magnetic } \\
\text { fields, or light. 2) Permanent and nonpermanent records shall be } \\
\text { properly packaged by being firmly attached in binders or piaced in } \\
\text { folders or envelopes for storage in steel file cabinets, on shelving, or } \\
\text { in containers. Magnetic or electronic media shall be protected from } \\
\text { magnetic fields and from the conditions listed in } 1 \text { above. 3) } \\
\text { Measures shall be established to provide replacement of lost or } \\
\text { damaged records. When replacement or restoration cannot be } \\
\text { achieved, an Occurrence Reporting System Form will be prepared, } \\
\text { and the resulting recommendations shall be followed. 4) Measures } \\
\text { shall be established to guard against larceny and vandalism and to } \\
\text { preclude entry of unauthorized personnel into the records storage } \\
\text { area. }\end{array}$ \\
\hline
\end{tabular}


Table 2 (continued)

\begin{tabular}{|c|c|c|c|}
\hline \multicolumn{3}{|c|}{ Administrative and tochnical basis } & \multirow{2}{*}{$\begin{array}{l}\text { Low } 1 \text { doamen member } 10-101, \text { Records Management, Rev. } 2 \\
\text { Requirement unit text/comments }\end{array}$} \\
\hline Compliance document & $\begin{array}{c}\text { Level } 1 \\
\text { document section }\end{array}$ & Flowdown status & \\
\hline & $\begin{array}{l}\text { ESS-QA-17.0 } \\
\text { V.N. }\end{array}$ & $\begin{array}{l}\text { Complete } \\
\text { Section C-15; } \\
\text { Appendix B-2,3 }\end{array}$ & $\begin{array}{l}\text { Records shall be stored in facilities constructed in facilities } \\
\text { constructed and maintained so as to minimize the risk of damage or } \\
\text { destruction of records from the following: } \\
\text { 1) natural disasters such as wind, flood, and fire; } \\
\text { 2) environmental conditions such as high and low temperatures and } \\
\text { humidity; 3) infestations of insects, molds, or rodents. }\end{array}$ \\
\hline & $\begin{array}{l}\text { ESS-QA-17.0 } \\
\text { V. O. }\end{array}$ & $\begin{array}{l}\text { Complete; C-3 } \\
\text { Appendix B-2 }\end{array}$ & $\begin{array}{l}\text { In-plant storage systems shall provide for timely retrieval, normally } \\
\text { not to exceed } 4 \text { hours from the time the document or records are } \\
\text { requested. }\end{array}$ \\
\hline & $\begin{array}{l}\text { ESS-QA-17.0 } \\
\text { V. P. }\end{array}$ & $\begin{array}{l}\text { Complete } \\
\text { Section C-4, } 13\end{array}$ & $\begin{array}{l}\text { Listings shall be maintained and posted at the entrance of the } \\
\text { records storage area to designate those personnel who shall have } \\
\text { access to the stored records. }\end{array}$ \\
\hline & $\begin{array}{l}\text { ESS-QA-17.0 } \\
\text { V. Q. }\end{array}$ & $\begin{array}{l}\text { Complete } \\
\text { Section A-3; } \\
\text { Appendix B-1 }\end{array}$ & $\begin{array}{l}\text { Records maintained by suppliers, vendors, or subcontractors at their } \\
\text { facilities or other locations shall be accessible to individuals } \\
\text { designated by Energy Systems, as required by specifications or } \\
\text { contract. }\end{array}$ \\
\hline & $\begin{array}{l}\text { ESS-QA-17.0 } \\
\text { V. R. }\end{array}$ & $\begin{array}{l}\text { Complete } \\
\text { Section A-3; } \\
\text { Appendix B-1 }\end{array}$ & $\begin{array}{l}\text { Records accumulated at various locations before transfer shall be } \\
\text { made accessible to designated Energy Systems representatives for } \\
\text { evaluation, as required by specifications or contract. }\end{array}$ \\
\hline & $\begin{array}{l}\text { ESS-EM-112, 8/8/14/92, } \\
\text { Emergency Operating Records } \\
\text { Protection Program } \\
\text { IV B }\end{array}$ & $\begin{array}{l}\text { Complete; } \\
\text { Appendix C-3 }\end{array}$ & $\begin{array}{l}\text { Each site shall develop a site specific list of emergency operating } \\
\text { records. }\end{array}$ \\
\hline & $\begin{array}{l}\text { ESS-EM-112 } \\
\text { IV C }\end{array}$ & $\begin{array}{l}\text { Complete; } \\
\text { Appendix C-3 }\end{array}$ & $\begin{array}{l}\text { Each site shall maintain certain Emergency Operating Records in or } \\
\text { accessible to the EOC/Emergency Control Center (ECC). }\end{array}$ \\
\hline
\end{tabular}


Table 2 (continued)

\begin{tabular}{|c|c|c|c|}
\hline \multicolumn{3}{|c|}{ Administrative and technical basis } & \multirow[t]{2}{*}{ Lnel I doxmanmex IO-101, Reconds Management, Rev. 2} \\
\hline Compliance document & $\begin{array}{l}\text { Level } 1 \\
\text { document section }\end{array}$ & Flowdown status & \\
\hline & $\begin{array}{l}\text { ESS-EM-112 } \\
\text { IV D }\end{array}$ & $\begin{array}{l}\text { Complete; } \\
\text { Appendix C-3 }\end{array}$ & $\begin{array}{l}\text { If the records are not located physically in the EOC/ECC, a list of } \\
\text { the documents and locations shall be available in the EOC/ECC. In } \\
\text { addition to the list, a call-in roster of persons needed to access and } \\
\text { interpret the documents shall be maintained. }\end{array}$ \\
\hline & $\begin{array}{l}\text { ESS-EM-112 } \\
\text { IV E }\end{array}$ & $\begin{array}{l}\text { Complete; } \\
\text { Appendix C-3 }\end{array}$ & $\begin{array}{l}\text { Records must be in a medium that is readable under any likely } \\
\text { emergency condition. }\end{array}$ \\
\hline & $\begin{array}{l}\text { ESS-EM-112 } \\
\text { IV F }\end{array}$ & $\begin{array}{l}\text { Complete; } \\
\text { Appendix C-3 }\end{array}$ & $\begin{array}{l}\text { The required Emergency Operating Records include as a minimum } \\
\text { (official record copies shall not be used): 1) site emergency plans; } 2 \text { ) } \\
\text { emergency preparedness/response procedures; 3) site Safeguards } \\
\text { and Security Plan/Master Safeguards and Security Agreement; 4) } \\
\text { security patrol/protective forces procedures; 5) site and area maps; } \\
\text { 6) engineering drawings; 7) prefire plans; 8) hazard and } \\
\text { consequence assessments including locations and quantities of } \\
\text { material; 9) emergency equipment and supplies; 10) site succession } \\
\text { of command; 11) description of essential emergency functions; 12) } \\
\text { lists of key personnel (EOC Cadre, emergency response teams, } \\
\text { employees with special skills, procurement personnel and emergency } \\
\text { call lists); 13) location of complex industrial records (as applicable); } \\
\text { 14) location of special nuclear materials inventories. }\end{array}$ \\
\hline & $\begin{array}{l}\text { ESS-EM-112 } \\
\text { IV G }\end{array}$ & $\begin{array}{l}\text { Complete; } \\
\text { Appendix C-3 }\end{array}$ & $\begin{array}{l}\text { All Emergency Operating Records shall be identified and stored in } \\
\text { accordance with the improved level of fire protection required by } \\
5480.7\end{array}$ \\
\hline & $\begin{array}{l}\text { ESS-EM-112 } \\
\text { IV H }\end{array}$ & $\begin{array}{l}\text { Complete; } \\
\text { Appendix C-3 }\end{array}$ & $\begin{array}{l}\text { Storage of classified documents shall be approved in accordance } \\
\text { with DOE 5634.1A. }\end{array}$ \\
\hline & $\begin{array}{l}\text { ESS-EM-112 } \\
\text { IV I }\end{array}$ & $\begin{array}{l}\text { Complete; } \\
\text { Appendix C-3 }\end{array}$ & $\begin{array}{l}\text { EOC Cadre members shall receive training on the location and } \\
\text { availability of Emergency Operating Records. }\end{array}$ \\
\hline
\end{tabular}


Table 2 (continued)

\begin{tabular}{|c|c|c|c|}
\hline \multicolumn{3}{|c|}{ Administrative and technical besis } & \multirow[t]{2}{*}{ Lovel 1 documax mumber 10-101, Reconds Management, Rev. 2} \\
\hline Compliance document & $\begin{array}{c}\text { Level } 1 \\
\text { document section }\end{array}$ & Flowdown status & \\
\hline & $\begin{array}{l}\text { ESS-EH-101, 3/15/93, } \\
\text { Environmental, Safety, and } \\
\text { Health Activities Required } \\
\text { Records } \\
\text { Section V.A }\end{array}$ & $\begin{array}{l}\text { Complete; A } \\
\text { Appendix C-2 }\end{array}$ & $\begin{array}{l}\text { Central and site Environmental Safety and Health (ES\&H), Waste } \\
\text { Management (WM), and ER organizations shall maintain the } \\
\text { appropriate records required by Federal, state, and local laws, } \\
\text { regulations and rules, standards, guidelines, operating codes, and } \\
\text { Codes of Federal Regulations, in addition to those described in the } \\
\text { Appendix to this standard and other Energy Systems standards and } \\
\text { procedures. These records may already exist or need to be } \\
\text { generated, collected, maintained, and retained indefinitely or until } \\
\text { otherwise directed by this standard. Central ES\&H organizations } \\
\text { shall maintain copies of current corporate directives. } \\
\text { The Appendix is a } 4 \text { page listing of required records. }\end{array}$ \\
\hline & $\begin{array}{l}\text { ESS-EH-101 } \\
\text { Section V. B. }\end{array}$ & $\begin{array}{l}\text { Complete; A; B } \\
\text { Appendix C-2 }\end{array}$ & $\begin{array}{l}\text { Central and site ES\&H, WM, and ER organizations will keep, as a } \\
\text { minimum, a list and location of the records maintained to fulfill } \\
\text { these requirements. }\end{array}$ \\
\hline & $\begin{array}{l}\text { ESS-EH-101 } \\
\text { Section V. C }\end{array}$ & $\begin{array}{l}\text { Complete; } \\
\text { Appendix C-2 }\end{array}$ & $\begin{array}{l}\text { Central and site ES\&H, WM, and ER organizations shall establish } \\
\text { record management systems for efficient and quick retrieval. }\end{array}$ \\
\hline & $\begin{array}{l}\text { ESS-EH-101 } \\
\text { Section V. D. }\end{array}$ & $\begin{array}{l}\text { Complete; } \\
\text { Appendix C-2 }\end{array}$ & $\begin{array}{l}\text { Central and site ES\&H, WM and Er organizations shall establish } \\
\text { identification criteria and implement the process to designate QA } \\
\text { records and permanent, lifetime records for required maintenance } \\
\text { and retention. }\end{array}$ \\
\hline & $\begin{array}{l}\text { ESS-IO-102, Rights and } \\
\text { Interests Records Protection } \\
\text { Program, 4/16/93 } \\
\text { Section V.B }\end{array}$ & $\begin{array}{l}\text { Complete; Appendix } \\
\text { C-4 }\end{array}$ & $\begin{array}{l}\text { Installations shall develop a specific list of Rights and Interests } \\
\text { Records. Records shall be listed by title and include contact person } \\
\text { and location. Refer to Appendix A for categories of required Rights } \\
\text { and Interests Records. Others may be added as approved by } \\
\text { Site/Major Organizations and Energy Systems. }\end{array}$ \\
\hline
\end{tabular}


Table 2 (continued)

\begin{tabular}{|c|c|c|c|}
\hline \multicolumn{3}{|c|}{ Administrative and technical besis } & \multirow{2}{*}{$\begin{array}{l}\text { 10-101, Reconds Management, Rev. } 2 \\
\text { Requirement unit text/comments } \\
\end{array}$} \\
\hline Compliance document & $\begin{array}{c}\text { Level } 1 \\
\text { document section }\end{array}$ & Flowdown status & \\
\hline & $\begin{array}{l}\text { ESS-IO-102 } \\
\text { Section V.C }\end{array}$ & $\begin{array}{l}\text { Complete; } \\
\text { Appendix C-4 }\end{array}$ & $\begin{array}{l}\text { Identification, storage, maintenance, and disposition of Rights and } \\
\text { Interests Records for each installation shall be done in accordance } \\
\text { with written instructions incorporating requirements and agreements, } \\
\text { (i.e., Records Inventory \& Disposition Schedules). }\end{array}$ \\
\hline & $\begin{array}{l}\text { ESS-IO-102 } \\
\text { Section V. D }\end{array}$ & $\begin{array}{l}\text { Complete; } \\
\text { Appendix C-4 }\end{array}$ & $\begin{array}{l}\text { Rights and Interests Records may be in any medium for which } \\
\text { readability will be feasible. }\end{array}$ \\
\hline & $\begin{array}{l}\text { ESS-1O-102 } \\
\text { Section V. E }\end{array}$ & $\begin{array}{l}\text { Complete; } \\
\text { Appendix C-4 }\end{array}$ & $\begin{array}{l}\text { Location of rights and interests records and the use of duplicate } \\
\text { copies shall be determined on a records series basis. }\end{array}$ \\
\hline & $\begin{array}{l}\text { ESS-IO-102 } \\
\text { Section V. F }\end{array}$ & $\begin{array}{l}\text { Complete; Appendix } \\
\text { C-4 }\end{array}$ & $\begin{array}{l}\text { A determination shall be made as to whether the original or official } \\
\text { record copy or a duplicate will be designated as the Rights and } \\
\text { Interests Record. If the original or official record copy is used, there } \\
\text { shall be agreement among the Department of Energy (DOE), } \\
\text { Energy Systems, and the Site/Major Organizations; and storage } \\
\text { locations used shall meet the risk level of fire protection required by } \\
\text { DOE Order 5480.7, Fire Protection. }\end{array}$ \\
\hline & $\begin{array}{l}\text { ESS-IO-102 } \\
\text { Section V. G }\end{array}$ & $\begin{array}{l}\text { Complete; } \\
\text { Appendix C-4 }\end{array}$ & $\begin{array}{l}\text { Persons assigned the responsibility of maintaining Rights and } \\
\text { Interests Records shall receive training on identification, location, } \\
\text { and availability of Rights and Interests Records. }\end{array}$ \\
\hline & $\begin{array}{l}\text { ESS-1O-102 } \\
\text { Section V. H }\end{array}$ & $\begin{array}{l}\text { Complete; } \\
\text { Appendix C-4 }\end{array}$ & $\begin{array}{l}\text { Annual reviews of Rights and Interests Records shall be conducted } \\
\text { at each site. }\end{array}$ \\
\hline $\begin{array}{l}\text { DOE Radiological Control } \\
\text { Manual (6/92) Radiological } \\
\text { Records, Chapter } 7\end{array}$ & $\begin{array}{l}\text { Appendix C, } 1 \text { B refers user to } \\
\text { this document }\end{array}$ & Complete & \\
\hline
\end{tabular}




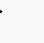


Table 3. DOE-ORO ER Program and Energy Systems records management and document control requirement units ESS-IO-201, Document Control, Rev. 2

\begin{tabular}{|c|c|c|c|}
\hline \multicolumn{3}{|c|}{ Administrative and technical bessis } & \multirow{2}{*}{$\begin{array}{c}\text { Lend 1 docenen number ESS-IO-201, Document Control, Rev-2 (8/20/93) } \\
\begin{array}{c}\text { Requirement unit } \\
\text { text/comments }\end{array}\end{array}$} \\
\hline Compliance document & $\begin{array}{c}\text { Level } 1 \\
\text { document section }\end{array}$ & Flowdown status & \\
\hline $\begin{array}{l}\text { DOE 4700.1, 3/6/87, } \\
\text { Project Management } \\
\text { System } \\
\text { Chapter III,Part D, 2f }\end{array}$ & $\begin{array}{l}\text { IO-201, Document Control, } \\
\text { Rev. } 2 \\
\text { Sections A,B,C,D,E,F,G,H,K }\end{array}$ & Complete & $\begin{array}{l}\text { Document control is a means by which all program documentation } \\
\text { can be controlled, tracked, and updated in a timely manner to } \\
\text { ensure that applicability and correctness shall be established. The } \\
\text { control measures, which should be initiated and followed, should } \\
\text { assure that such documents are reviewed for adequacy, approved } \\
\text { for release by authorized personnel, and are distributed to and used } \\
\text { at the location of the prescribed activity. }\end{array}$ \\
\hline $\begin{array}{l}\text { DOE 5480.19, 7/9/90, } \\
\text { Conduct of Operations } \\
\text { Requirements for DOE } \\
\text { Facilities } \\
\text { Chapter XVI, C, } 6 \\
\text { Para. } 2 \\
\end{array}$ & $\begin{array}{l}\text { IO-201 } \\
\text { Sections E,F,G,K,1 }\end{array}$ & Partial & $\begin{array}{l}\text { Working copies should be controlled and a system should be in } \\
\text { place to ensure that outdated procedures are not used by mistake } \\
\text { and that working copies are replaced according to approved } \\
\text { procedures. } \\
\text { Worting copies of controlled documents are not specifically } \\
\text { addressed. }\end{array}$ \\
\hline $\begin{array}{l}\text { DOE } 5480.19 \\
\text { Chapter XVI, C } 3,4\end{array}$ & $\begin{array}{l}\text { IO-201 } \\
\text { Sections A, B }\end{array}$ & Also covered by MS 151 & $\begin{array}{l}\text { Procedure changes and revisions. Change refers to an on-the-spot } \\
\text { change; does not involve retyping or reissuing. Revisions constitute a } \\
\text { new, retyped edition of the procedure....All currently effective } \\
\text { changes should normally be incorporated when the procedure is } \\
\text { revised.....Revisions should receive the same depth of review and } \\
\text { level of approval as the initial versions. New and revised procedures } \\
\text { should be approved prior to use. }\end{array}$ \\
\hline $\begin{array}{l}\text { DOE } 5480.19 \\
\text { Chapter VIII, } 10 .\end{array}$ & $\begin{array}{l}\text { IO-201 } \\
\text { Sections E, F, I, K }\end{array}$ & Complete & $\begin{array}{l}\text { A system should be established to ensure that the operations } \\
\text { personnel receive and utilize the latest revisions of engineering } \\
\text { drawings and specifications. }\end{array}$ \\
\hline $\begin{array}{l}\text { DOE 5481.1B, 9/23/86, } \\
\text { Safety Analysis and } \\
\text { Review System } \\
\text { Chapter I, Part 3, d. }\end{array}$ & $\begin{array}{l}\text { IO-201 } \\
\text { Section A }\end{array}$ & Complete & $\begin{array}{l}\text { This reference defines safety analysis reports as controlled } \\
\text { documents. }\end{array}$ \\
\hline
\end{tabular}


Table 3 (continued)

\begin{tabular}{|c|c|c|c|}
\hline \multicolumn{3}{|c|}{ Administrative and technical besis } & \multirow{2}{*}{$\frac{\text { Lend 1 deamen number ESS-10-201, Document Control, Rev-2 (8/20/93) }}{\begin{array}{c}\text { Requirement unit } \\
\text { text/comments }\end{array}}$} \\
\hline Compliance document & $\begin{array}{c}\text { Level } 1 \\
\text { document section }\end{array}$ & Flowdown status & \\
\hline $\begin{array}{l}\text { DOE 5500.3A, 4/30/91, } \\
\text { Planning and } \\
\text { Preparedness for } \\
\text { Operational Emergencies } \\
11 \text { c (13) (b) }\end{array}$ & $\begin{array}{l}\text { IO-201 } \\
\text { Section A }\end{array}$ & Complete & $\begin{array}{l}\text { This reference defines emergency operating plans and procedures as } \\
\text { controlled documents. }\end{array}$ \\
\hline $\begin{array}{l}\text { DOE 5700.6C, } 8 / 21 / 91 \text {, } \\
\text { Quality Assurance } \\
\text { 9.c. (d) }\end{array}$ & $\begin{array}{l}\text { 10-201 } \\
\text { Sections A - K }\end{array}$ & Complete & $\begin{array}{l}\text { Documents shall be prepared, reviewed, approved, issued, used, and } \\
\text { revised to prescribe processes, specify requirements, or establish } \\
\text { design. }\end{array}$ \\
\hline $\begin{array}{l}\text { DOE } 5700.6 \mathrm{C} \\
\text { Attachment I, 4.a.(1) }\end{array}$ & $\begin{array}{l}\text { IO-201 } \\
\text { Procedure }\end{array}$ & Complete & $\begin{array}{l}\text { A process should be established and implemented to control } \\
\text { preparation, review, approval, issuance, use, and revision of } \\
\text { documents that establish policies, prescribe work, specify } \\
\text { requirements, or establish design. }\end{array}$ \\
\hline $\begin{array}{l}\text { DOE } 5700.6 \mathrm{C} \\
\text { Attachment I, 4.a.(2) }\end{array}$ & $\begin{array}{l}\text { IO-201 } \\
\text { Sections "Applies To", A }\end{array}$ & Complete & $\begin{array}{l}\text { The scope of the document control system should be defined. } \\
\text { Examples of documents to be controlled should include drawings, } \\
\text { data files ( including various media), calculations, specifications, } \\
\text { computer codes, purchase orders and related documents, vendor- } \\
\text { supplied documents, procedures, work instructions, operator aids, } \\
\text { and data sheets. }\end{array}$ \\
\hline $\begin{array}{l}\text { DOE } 5700.6 \mathrm{C} \\
\text { Attachment I, 4.a.(3) }\end{array}$ & $\begin{array}{l}\text { IO-201 } \\
\text { Sections B, E, F }\end{array}$ & $\begin{array}{l}\text { Partial } \\
\text { Procedure does not state } \\
\text { specific times for distribution } \\
\text { process. }\end{array}$ & $\begin{array}{l}\text { Revisions to controlled documents should be reviewed and } \\
\text { approved by the organization that originally reviewed and approved } \\
\text { the documents. An alternative organization may be designated } \\
\text { based on technical competence and capability. Timeliness guidelines } \\
\text { should implemented for distribution of new or revised controlled } \\
\text { documents. }\end{array}$ \\
\hline $\begin{array}{l}\text { DOE } 5700.6 \mathrm{C} \\
\text { Attachment I, 4.a.(4) }\end{array}$ & $\begin{array}{l}\text { IO-201 } \\
\text { Sections Purpose, E }\end{array}$ & Complete & $\begin{array}{l}\text { Controlled documents should be distributed to and used by } \\
\text { personnel performing work. }\end{array}$ \\
\hline
\end{tabular}


Table 3 (continued)

\begin{tabular}{|c|c|c|c|}
\hline \multicolumn{3}{|c|}{ Administrative and technical basts } & \multirow{2}{*}{$\begin{array}{c}\text { Lend } 1 \text { decoumen number ESS-1O-201, Document Controh, Rev-2 (8/20/93) } \\
\begin{array}{c}\text { Requirement unit } \\
\text { text/comments }\end{array}\end{array}$} \\
\hline Compliance document & $\begin{array}{c}\text { Level } 1 \\
\text { document section }\end{array}$ & Flowdown status & \\
\hline $\begin{array}{l}\text { DOE } 5700.6 \mathrm{C} \\
\text { Attachment I, 4.a.(5) }\end{array}$ & $\begin{array}{l}\text { IO-201 } \\
\text { Sections E, F }\end{array}$ & Complete & $\begin{array}{l}\text { Control of superseded and cancelled documents should include } \\
\text { measures to ensure that only correct documents are in use. Record } \\
\text { copies should be marked "superseded" or "cancelled" and kept for a } \\
\text { specified retention period. }\end{array}$ \\
\hline $\begin{array}{l}\text { NQA-1, Basic } \\
\text { Requirement } 6\end{array}$ & $\begin{array}{l}\text { IO-201 } \\
\text { Sections A, B, E }\end{array}$ & Complete & $\begin{array}{l}\text { The preparation, issue, and change of documents that specify quality } \\
\text { requirements or prescribe activities affecting quality shall be } \\
\text { controlled to assure that correct documents are being employed. } \\
\text { Such documents, including changes thereto, shall be reviewed for } \\
\text { adequacy and approved for release by authorized personnel. }\end{array}$ \\
\hline $\begin{array}{l}\text { NQA-1, Supplement } \\
\text { 6S-1 } \\
1 \text {, Paragraph } 2\end{array}$ & $\begin{array}{l}\text { IO-201 } \\
\text { Section Applies To, and I }\end{array}$ & Complete & $\begin{array}{l}\text { The documents which shall be controlled in accordance with this } \\
\text { Supplement are only those documents which specify quality } \\
\text { requirements or prescribe activities affecting quality such as } \\
\text { instructions, procedures, and drawings. }\end{array}$ \\
\hline $\begin{array}{l}\text { NQA-1, Supplement } \\
\text { 6S-1 } \\
\text { 1, Paragraph } 3\end{array}$ & $\begin{array}{l}\text { 1O-201 } \\
\text { Sections: Purpose, A, B, E, F }\end{array}$ & Complete & $\begin{array}{l}\text { The term document control used throughout this Supplement is } \\
\text { defined as the act of assuring that documents are reviewed for } \\
\text { adequacy, approved for release by authorized personnel, and } \\
\text { distributed to and used at the location where the prescribed activity } \\
\text { is performed. }\end{array}$ \\
\hline $\begin{array}{l}\text { NQA-1, Supplement } \\
6 S-1 \\
2\end{array}$ & $\begin{array}{l}\text { 10-201 } \\
\text { Sections: Applies To, A, } \\
\text { C-3 }\end{array}$ & Complete & $\begin{array}{l}\text { The control system shall be documented and provide for a-c: } \\
\text { a) identification of documents to be controlled and their specified } \\
\text { distribution; b) identification of assignment of responsibility for } \\
\text { preparing, reviewing, approving, and issuing documents; c) review of } \\
\text { documents for adequacy, completeness, and correctness before } \\
\text { approval and issuance. }\end{array}$ \\
\hline
\end{tabular}


Table 3 (continued)

\begin{tabular}{|c|c|c|c|}
\hline \multicolumn{3}{|c|}{ Administrative and tochmical besis } & \multirow{2}{*}{ 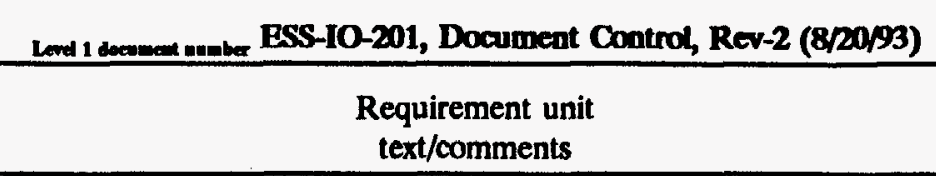 } \\
\hline Compliance document & $\begin{array}{c}\text { Level } 1 \\
\text { document section }\end{array}$ & Flowdown status & \\
\hline $\begin{array}{l}\text { NQA-1, Supplement } \\
\text { 6S-1 } \\
3.1\end{array}$ & $\begin{array}{l}\text { IO-201 } \\
\text { Section B }\end{array}$ & Complete & $\begin{array}{l}\text { Changes to document, other than those defined as minor changes in } \\
\text { para. } 3.2 \text { below, are considered as major changes and shall be } \\
\text { reviewed and approved by the same organizations that performed } \\
\text { the original review and approval unless other organizations are } \\
\text { specifically designated. The reviewing organization shall have access } \\
\text { to pertinent background data or information upon which to base } \\
\text { approval. }\end{array}$ \\
\hline $\begin{array}{l}\text { NQA-1, Supplement } \\
65-1 \\
3.2\end{array}$ & $\begin{array}{l}\text { IO-201 } \\
\text { Section B }\end{array}$ & Complete & $\begin{array}{l}\text { Minor changes to documents, such as inconsequential editorial } \\
\text { corrections, shall not require that the revised documents receive the } \\
\text { same review and approval as the original documents. To avoid a } \\
\text { possible omission of a required review, the type of minor changes } \\
\text { that do not require such a review and approval and the persons who } \\
\text { can authorize such a decision shall be clearly delineated. }\end{array}$ \\
\hline
\end{tabular}




\section{DISTRIBUTION}

1. H. L. Boston

2. S. L. Burnham

3. R. B. Cook

4. K. W. Cook

5. T. L. Dahl

6. M. F. P. Delozier

7. J. T. Grumski

8. R. A. Lawson

9. J. R. Lyons

10. D. M. Matteo

11. T. W. Morris

12. K. T. O'Kane

13. P. T. Owen

14. R. B. Retteberg

15. B. Watts

16. E. Vasquez

17. ER Document Management Center

18. K-25 Site Records

19. ORNL Laboratory Records

20. S. S. Perkins, DOE Oak Ridge Operations Office, P.O. Box 2001, Oak Ridge, TN 37831-8541

21. R. C. Sleeman, DOE Oak Ridge Operations Office, P.O. Box 2001, Oak Ridge, TN 37831-8541 